\title{
5. VARIABILITY IN THE HYDROTHERMAL COMPONENT OF THE SEDIMENTARY SEQUENCE IN THE LAU BACKARC BASIN (SITES 834-839) ${ }^{1}$
}

\author{
R.A. Hodkinson ${ }^{2}$ and D.S. Cronan ${ }^{2}$
}

\begin{abstract}
Sediment samples $(N=872)$ from the six Ocean Drilling Program Leg 135 backarc sites were analyzed in bulk and by $\mathrm{HCl}$ selective leach using ICPAES techniques. The use of an $\mathrm{HCl}$ selective leach, with subsequent carbonate correction, allowed the removal of the dilutive effect of both the volcaniclastic and biogenic carbonate phases on the nondetrital component of the sediments.

Multivariate statistical analysis (factor analysis) of the corrected data resolved two sediment phases: a hydrothermal oxide phase, with loadings of $\mathrm{Mn}, \mathrm{Fe}$, and associated coprecipitated elements; and a weathered detrital phase. Factor scores for the hydrothermal oxide phase were used to assess the temporal variability in hydrothermal input to the basin.

Sites 834 and 835 exhibit considerably higher hydrothermal inputs than the remaining backarc sites. With the exception of Site 836, all sites show an increase in hydrothermal input uphole from the base of the sediment section to a peak in input before decreasing to surface. Such trends suggest an increase in hydrothermal input to the sediments related to the propagation of spreading ridges into the older basin crust formed by extensional rifting. Data suggest that a period of time is required after ridge propagation before hydrothermal discharge from the newly formed spreading ridge becomes fully established and maximum hydrothermal input to adjacent sediments is recorded.

Peaks in hydrothermal input, superimposed on the general downhole trends, are likely to reflect tectonism and style of ridge propagation within the basin, whereas variations in rates of change of hydrothermal input may reflect variations in crustal spreading rates.
\end{abstract}

\section{INTRODUCTION AND BACKGROUND}

Hydrothermal mineral deposits have been widely reported in the Lau Basin following the first discovery of hydrothermal barite and opal by Bertine and Keene (1975). The first occurrence of hydrothermal manganese crust and nontronite in the basin was described by von Stackelberg et al. (1985) from the Central Lau Spreading Center (CLSC) and from the Valu Fa Ridge. Sulfide-impregnated basalts, barite, and limonite were also reported from this latter area. Subsequent, more detailed work by von Stackelberg et al. (1988) identified widespread hydrothermal activity at both the CLSC and the Valu Fa Ridge, including the occurrence of an "extinct" black smoker chimney and benthic organisms associated with hydrothermal fields adjacent to the Valu Fa Ridge. A similar occurrence of an "extinct" black smoker was also reported by Hawkins and Helu (1986) in the northeastern part of the basin. A French/German submersible expedition to the Valu Fa Ridge in 1989 found extensive, active hydrothermal fields containing large biological communities, hydrothermal discharges with temperatures up to $400^{\circ} \mathrm{C}$, and numerous polymetallic sulfides rich in $\mathrm{Cu}, \mathrm{Zn}, \mathrm{Fe}$, and $\mathrm{Ba}$ (Fouquet et al., 1990).

The occurrence of mixed ferromanganese oxides in Lau Basin sediments was first documented by Bertine (1974). Hydrothermal inputs to sediments in the Lau Basin were assessed by Cronan (1983) and, as a result of a surface sediment sampling program, ferromanganese oxides of hydrothermal origin were reported in the central part of the basin (Cronan et al., 1984). A regional geochemical study of surface sediments in the area (Hodkinson et al., 1986) showed such oxides to be widely dispersed throughout the basin. A study of nondetrital element accumulation rates in short sediment cores from the CLSC, and along a traverse westward away from the CLSC at the latitude of Sites 834 and 835 , showed that these recent sediments exhibited elevated accumulation rates of certain hydrothermally associated elements (Cronan et al., 1986). These accumulation rates are

\footnotetext{
${ }^{1}$ Hawkins, J., Parson, L., Allan, J., et al., 1994. Proc. ODP, Sci. Results, 135: College Station, TX (Ocean Drilling Program).

${ }^{2}$ Department of Geology, Royal School of Mines, Imperial College of Science, Technology and Medicine, Prince Consort Road, London SW7 2BP, United Kingdom.
}

comparable with those of sediments from the East Pacific Rise and confirm a substantial hydrothermal input to the Lau Basin sediments.

A study of short sediment cores by Reich (1990) identified elevated accumulation rates of hydrothermal matter adjacent to both the CLSC and the Valu Fa Ridge. Walter et al. (1990) have shown that the maximum oxide content of the recent sediments $(35 \%$ on a carbonate-free basis) occurs in the southern Lau Basin in the vicinity of the Valu Fa Ridge. In addition, Walter et al. (1990) used multivariate statistics to demonstrate that sediments away from areas of currently known tectonic activity also exhibit a strong hydrothermal influence, suggesting widespread dispersion of hydrothermal oxides and/or localized hydrothermal sources.

Most recently, a study of surface sedimients throughout the central part of the Lau Basin (Hodkinson and Cronan, 1991) used a combination of selective chemical leaching and multivariate statistics (factor analysis) to assess the nature and variability of the nondetrital sediment component. Previous studies in the basin (Hodkinson et al., 1986; Cronan et al., 1986) have shown that the sediments comprise mixtures of detrital and nondetrital components (such as biogenic carbonate, volcanic detritus, hydrothermal precipitates, and other minor phases) and have demonstrated that the proportion of a particular element that is detrital or nondetrital in origin varies significantly between different sediment samples. This variation for each individual element is controlled by the amount of a particular sedimentary component incorporated into the bulk sediment sample. By using a selective leaching technique, combined with carbonate correction, it is possible to remove the varying dilutive effect of two major sedimentary constituents on individual bulk element concentrations, namely biogenic carbonate and volcaniclastic detritus, to assess more closely the variability in the chemistry of the nondetrital/nonbiogenic sediment phase. This approach, combined with multivariate statistics, resulted in the identification of a "weathered volcanic detrital component" and two hydrothermal phases in the Lau Basin surface sediments: an "oxide phase" with associations of $\mathrm{Mn}, \mathrm{Fe}, \mathrm{Co}, \mathrm{Ni}$, and $\mathrm{Cu}$ and a "sulfide/weathered sulfide products" phase with associations of $\mathrm{Fe}, \mathrm{Cu}$, and $\mathrm{Zn}$ (Hodkinson and Cronan, 1991). Factor scores used to assess the basinwide variability of the hydrothermal phases showed that the "sulfide/weathered sulfide products" phase is primarily associated with sediments from the active 
neovolcanic ridge complexes whereas the "oxide phase" is, as expected, more widely dispersed away from these ridge complexes.

All of these studies, however, have dealt solely with surface sediments and relatively short sediment cores and have not addressed the question of long-term temporal variability in the hydrothermal component of the sediments throughout the evolution of the basin. One of the aims of Ocean Drilling Program (ODP) Leg 135 was to recover complete sedimentary sections down to basement at different localities in the basin in order to assess such variability.

This paper describes the results of studies on sediments collected from the first holes drilled at the six backarc sites (the "A" holes), in particular the hydrothermal component of the sediments, and uses similar techniques to those applied to surface sediments by Hodkinson and Cronan (1991).

\section{CORE LITHOLOGIES AND SAMPLES USED}

Of the six backarc sites drilled (Fig. 1), Sites 834 and 835 are situated in small, elongate north-trending sub-basins approximately 180 and $80 \mathrm{~km}$, respectively, to the west of the CLSC. The CLSC is the current site of crustal accretion at this latitude in the basin (Parson et al., 1990). Sites 836 to 839 are situated farther south, between 50 and $70 \mathrm{~km}$ west of the Eastern Lau Spreading Center (ELSC) (Fig. 1). All of the four latter sites occur within a $150 \times 50 \mathrm{~km}$ area and were drilled in three fault-bounded sub-basins. Sites 838 and 839 were drilled in the same sub-basin. With the exception of Site 838, basement was encountered at all backarc sites.

The sedimentary sequences at Sites 834 and 835 comprise predominantly ferromanganese-oxide-stained clayey nannofossil oozes containing turbiditic foraminifer sand and ooze interbeds and pyroclastic fallout ash layers (Parson, Hawkins, Allan, et al., 1992). These overlie a sequence of clayey nannofossil mixed sediments interbedded with turbiditic volcanic sands and silts that increase in thickness downhole. At Site 835 some of the clayey nannofossil ooze intervals of the sedimentary section have been redeposited in the form of mud-clast conglomerates and allochthonous sediment rafts (Parson, Hawkins, Allan, et al., 1992). At Sites 834 and 835, redeposition in the form of turbidites has been identified (Rothwell et al., this volume). Sites 836 to 839 show a sequence of ferromanganese-oxidestained clayey nannofossil ooze, with sparse volcaniclastic horizons, overlying thick sequences of volcaniclastic silts, sands, and pumiceous gravels (Parson, Hawkins, Allan, et al., 1992).

Leg 135 samples for this study were collected primarily from clayey nannofossil ooze lithologies. In all, 596 samples were obtained during the cruise. Based on the analytical data obtained for these samples (see "Analytical Methods" section, this chapter), periods of both enhanced and reduced hydrothermal input to the sediments at each site were initially identified. To define these periods more closely, a post-cruise follow-up sampling program collected an additional 276 samples, which were analyzed by the same techniques. The results presented here are based on this total data set of 872 samples.

\section{ANALYTICAL METHODS}

All samples were air dried at room temperature over silica gel and finely ground in agate vessels. Bulk chemical analyses were performed by inductively coupled plasma atomic emission spectroscopy (ICPAES) after total digestion with a mixture of nitric, perchloric, and hydrofluoric acids and subsequent leaching with $1 \mathrm{M} \mathrm{HCl}$ (Thompson and Walsh, 1989). Accuracy was checked with the use of certified international reference materials, along with in-house reference materials. No systematic errors were observed and accuracy was better than $5 \%$ for the elements studied here. Analytical precision was checked with the use of duplicate samples and was found to be better than $3 \%$ relative for the elements studied.

To assess the composition of the nondetrital fraction of the sediments, partition geochemistry of all samples has been undertaken

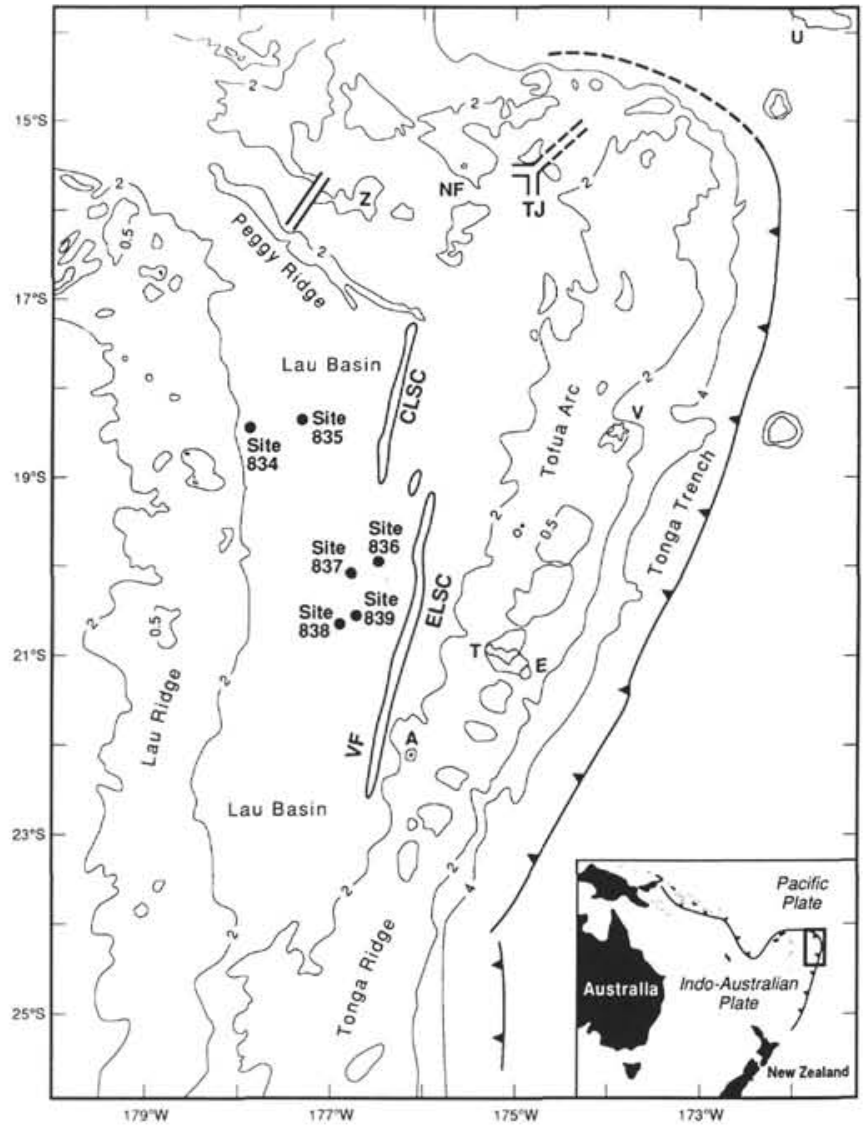

Figure 1. Location, simplified bathymetry, and major tectonic features of the Lau Basin region. $\mathrm{HT}=$ Havre Trough (northern limit); $Z=$ Zephyr Shoal. . Islands include $\mathrm{T}=$ Tongatapu, $\mathrm{E}=$ ' 'Eua, $\mathrm{V}=\mathrm{Vava}$ ' $\mathrm{u}, \mathrm{A}=\mathrm{\prime}^{\mathrm{A}} \mathrm{Ata}, \mathrm{NF}=\mathrm{Niaufo}$ 'ou, and $\mathrm{U}=$ Upolu. Major tectonic features include CLSC $=$ Central Lau Spreading Center, ELSC $=$ Eastern Lau Spreading Center, VF $=$ Valu Fa Ridge, and TJ = Niuafo'ou Triple Junction. Leg 135 site numbers and locations are shown. Bathymetric contour intervals in thousands of meters.

using an $\mathrm{HCl}$ leach to remove all but the resistant detrital phases of the sediments (Cronan, 1976). The sediments were leached using hot $50 \% \mathrm{HCl}$ and filtered through a $0.45 \mu \mathrm{m}$ filter. Composition of the leachate was again determined by ICPAES techniques, and precision was found to be better than $4 \%$ relative for all elements. The weight percent of individual samples soluble in the $\mathrm{HCl}$ leach was also determined using the dried filter residues.

\section{BULK GEOCHEMISTRY}

Table 1 provides a summary of the bulk geochemical data for each site, illustrating the typical element concentrations found and showing some general differences between the backarc sites.

Previous work on recent Lau Basin sediments (Hodkinson et al., 1986; Moorby et al., 1986; Walter et al., 1990) has shown that the bulk geochemistry of these sediments primarily reflects two major sediment types-biogenic carbonate and volcaniclastic detrituswith a hydrothermal ferromanganese oxide component superimposed upon these phases. Such a pattern is reflected here in the bulk geochemical data with Sites 834 and 835 showing typically higher $\mathrm{Ca}$ values, reflecting biogenic carbonate, and lower concentrations of volcaniclastically associated elements (such as $\mathrm{Al}$ and $\mathrm{Ti}$ ) than Sites 836 to 839 . This pattern correlates with shipboard lithologic data (Parson, Hawkins, Allan, et al., 1992), reflecting the more common occurrence of volcaniclastic detritus at Sites 836 to 839 compared 
Table 1. Summary of mean, minimum, and maximum bulk element concentrations at Sites 834 through 839.

\begin{tabular}{|c|c|c|c|c|c|c|}
\hline Element & $\begin{array}{l}\text { Site } 834 \\
(N=219)\end{array}$ & $\begin{array}{l}\text { Site } 835 \\
(N=248)\end{array}$ & $\begin{array}{l}\text { Site } 836 \\
(N=41)\end{array}$ & $\begin{array}{l}\text { Site } 837 \\
(N=91)\end{array}$ & $\begin{array}{l}\text { Site 838 } \\
(N=136)\end{array}$ & $\begin{array}{l}\text { Site } 839 \\
(N=137)\end{array}$ \\
\hline \multicolumn{7}{|l|}{$\mathrm{Li}(\mathrm{ppm})$ : } \\
\hline Mean & 6 & 8 & 7 & 9 & 8 & 8 \\
\hline Minimum & 1 & 3 & 3 & 4 & 2 & 3 \\
\hline Maximum & 24 & 82 & 47 & 19 & 21 & 20 \\
\hline \multicolumn{7}{|l|}{$\mathrm{K}(\%):$} \\
\hline Mean & 0.65 & 0.47 & 0.42 & 0.57 & 0.56 & 0.57 \\
\hline Minimum & 0.04 & 0.22 & 0.28 & 0.24 & 0.21 & 0.25 \\
\hline Maximum & 3.37 & 2.78 & 0.62 & 1.29 & 1.76 & 1.34 \\
\hline \multicolumn{7}{|l|}{$\mathrm{Be}(\mathrm{ppm})$ : } \\
\hline Mean & 0.45 & 0.37 & 0.37 & 0.38 & 0.41 & 0.38 \\
\hline Minimum & 0.05 & 0.10 & 0.13 & 0.15 & 0.15 & 0.15 \\
\hline Maximum & 2.20 & 1.48 & 0.73 & 0.78 & 0.93 & 0.85 \\
\hline \multicolumn{7}{|l|}{$\mathrm{Mg}(\%):$} \\
\hline Mean & 0.89 & 0.79 & 1.22 & 0.88 & 1.09 & 1.08 \\
\hline Minimum & 0.44 & 0.45 & 0.67 & 0.51 & 0.50 & 0.42 \\
\hline Maximum & 4.71 & 2.40 & 2.13 & 1.91 & 3.17 & 4.01 \\
\hline \multicolumn{7}{|l|}{$\mathrm{Ca}(\%):$} \\
\hline Mean & 20.2 & 22.6 & 16.1 & 16.5 & 14.5 & 14.3 \\
\hline Minimum & 3.1 & 2.3 & 6.89 & 2.7 & 1.8 & 2.4 \\
\hline Maximum & 34.8 & 30.3 & 23.2 & 26.8 & 26.4 & 25.5 \\
\hline \multicolumn{7}{|l|}{$\mathrm{Al}(\%):$} \\
\hline Mean & 2.83 & 2.26 & 3.90 & 3.60 & 4.29 & 4.16 \\
\hline Minimum & 0.21 & 1.03 & 2.11 & 1.68 & 1.55 & 1.76 \\
\hline Maximum & 8.82 & 5.97 & 6.42 & 7.09 & 9.04 & 7.95 \\
\hline \multicolumn{7}{|l|}{$\mathrm{Ti}$ (ppm): } \\
\hline Mean & 1680 & 1379 & 2409 & 1898 & 2662 & 2226 \\
\hline Minimum & 145 & 661 & 1113 & 1065 & 872 & 1042 \\
\hline Maximum & 6950 & 3911 & 5400 & 3482 & 6470 & 5320 \\
\hline \multicolumn{7}{|l|}{ V (ppm): } \\
\hline Mean & 181 & 163 & 197 & 104 & 134 & 138 \\
\hline Minimum & 12 & 53 & 130 & 31 & 29 & 23 \\
\hline Maximum & 1243 & 634 & 285 & 287 & 288 & 358 \\
\hline \multicolumn{7}{|l|}{ Mn (\%): } \\
\hline Minimum & 0.05 & $\begin{array}{l}2.12 \\
0.19\end{array}$ & $\begin{array}{l}1.31 \\
0.46\end{array}$ & $\begin{array}{l}0.87 \\
0.10\end{array}$ & $\begin{array}{l}1.10 \\
0.10\end{array}$ & $\begin{array}{l}0.84 \\
0.08\end{array}$ \\
\hline Maximum & 8.17 & 11.58 & 4.04 & 3.31 & 4.18 & 2.49 \\
\hline \multicolumn{7}{|l|}{$\mathrm{Fe}(\%):$} \\
\hline Mean & 4.31 & 3.99 & 5.19 & 3.46 & 4.25 & 4.11 \\
\hline Minimum & 0.22 & 1.83 & 3.72 & 2.19 & 1.88 & 2.16 \\
\hline Maximum & 10.51 & 9.82 & 7.83 & 5.91 & 7.39 & 7.05 \\
\hline \multicolumn{7}{|l|}{ Co (ppm): } \\
\hline Mean & 21 & 22 & 24 & 19 & 21 & 19 \\
\hline Minimum & 3 & 6 & 20 & 5 & 3 & 4 \\
\hline Maximum & 158 & 51 & 29 & 55 & 86 & 42 \\
\hline \multicolumn{7}{|l|}{$\mathrm{Ni}$ (ppm): } \\
\hline Mean & 71 & 88 & 65 & 44 & 50 & 47 \\
\hline Minimum & 4 & 21 & 28 & 4 & 2 & 2 \\
\hline Maximum & 232 & 251 & 151 & 97 & 163 & 122 \\
\hline \multicolumn{7}{|l|}{$\mathrm{Cu}$ (ppm): } \\
\hline $\begin{array}{l}\text { Mean } \\
\text { Minimum }\end{array}$ & $\begin{array}{r}177 \\
8\end{array}$ & $\begin{array}{r}182 \\
50\end{array}$ & 174 & 108 & 120 & 123 \\
\hline Maximum & $\begin{array}{r}8 \\
659\end{array}$ & $\begin{array}{r}58 \\
498\end{array}$ & $\begin{array}{l}104 \\
319\end{array}$ & 223 & $\begin{array}{r}11 \\
243\end{array}$ & $\begin{array}{r}24 \\
311\end{array}$ \\
\hline \multicolumn{7}{|l|}{$\mathrm{Zn}(\mathrm{ppm}):$} \\
\hline Mean & 95 & 95 & 91 & 67 & 85 & 80 \\
\hline Minimum & 4 & 39 & 70 & 46 & 52 & 49 \\
\hline Maximum & 485 & 252 & 213 & 97 & 157 & 476 \\
\hline $\mathrm{Pb}$ (ppm): & & & & & & \\
\hline Mean & 33 & 29 & 19 & 20 & 25 & 22 \\
\hline Minimum & 5 & 5 & 5 & 5 & 5 & 5 \\
\hline Maximum & 130 & 90 & 35 & 38 & 163 & 170 \\
\hline $\mathrm{P}(\mathrm{ppm}):$ & & & & & & \\
\hline Mean & 1457 & 1412 & 1200 & 865 & 928 & 999 \\
\hline Minimum & 262 & 516 & 606 & 280 & 318 & 240 \\
\hline Maximum & 3916 & 6160 & 1804 & 1628 & 1654 & 1880 \\
\hline
\end{tabular}

with Sites 834 and 835 . Bulk concentrations of elements with a known hydrothermal association, such as $\mathrm{Mn}$ and $\mathrm{Fe}$, show maximum values in Sites 834 and $835(8.17 \% \mathrm{Mn}$ and $10.51 \% \mathrm{Fe}$, and $11.58 \% \mathrm{Mn}$ and $9.82 \% \mathrm{Fe}$, respectively), significantly above those values in Sites 836 to 839. Associated elements, such as $\mathrm{Ni}, \mathrm{Cu}, \mathrm{V}$, and $\mathrm{P}$, show a similar trend, whereas other hydrothermally associated elements such as $\mathrm{Co}$,
$\mathrm{Zn}$, and $\mathrm{Pb}$ exhibit high bulk concentrations at Sites 836 to 839 as well as at Sites 834 and 835 .

\section{HCI-SOLUBLE DATA}

As discussed in the "Introduction and Background" section (this chapter), previous work has shown that in Lau Basin surface sediments not all of the bulk concentration of an element of known hydrothermal association in a particular sediment sample is hydrothermal in origin. A significant proportion of an element may be, for example, of volcaniclastic origin (e.g., Fe). This proportion may vary considerably among samples, depending on the degree of influence on the sample of particular sediment sources. To assess such variability, all samples have been leached using $50 \% \mathrm{HCl}$ (see "Analytical Methods" section, this chapter), which extracts all but the resistant detrital phases of the sediments.

Table 2 summarizes the means and ranges of the weight percent and percentages of individual elements soluble in this leach for each of the backarc sites.

Data show that the mean weight percent soluble is significantly higher at Sites 834 and 835 compared with Sites 836 to 839 , reflecting the lower abundance of detrital volcaniclastic sediment components at these two sites. For elements of known volcaniclastic association, such as $\mathrm{K}, \mathrm{Mg}, \mathrm{Al}$, and $\mathrm{Ti}$, significantly lower proportions are soluble in Sites 836 to 839 compared with Sites 834 and 835 . A significant proportion of these elements are, however, insoluble at Sites 834 and 835 , reflecting their partial detrital origin in all sediments. In contrast, the mean proportion of $\mathrm{Ca}$ that is $\mathrm{HCl}$-soluble is much higher at all sites $(76 \%$ to $96 \%$ ), reflecting its predominantly biogenic origin in the sediments. Slightly lower mean values do, however, occur at Sites 836 to 839 , indicating that small amounts of $\mathrm{Ca}$ do have a detrital origin. In the case of elements with a hydrothermal association, mean proportions of $\mathrm{HCl}$-soluble $\mathrm{Mn}, \mathrm{Ni}, \mathrm{Cu}$, and $\mathrm{Pb}$ are high at all sites, reflecting their largely nondetrital source. Iron, $\mathrm{Co}, \mathrm{Zn}, \mathrm{P}$, and V show similar high mean $\mathrm{HCl}$-soluble proportions in Sites 834 and 835, but these elements are significantly less soluble in Sites 836 to 839 (Table 2).

Although the mean $\mathrm{HCl}$-soluble percentages for hydrothermally associated elements show these general trends among sites, it is important to note the large variations among samples from the same site, evinced by the large range of $\mathrm{HCl}$-soluble percentages. This illustrates the differences in the source of an individual element (nondetrital vs. detrital) among different samples at the same site. By removing the detrital fraction of a particular element with known hydrothermal association for each individual sample, a more accurate assessment of the overall variation in hydrothermal input at each site can be made.

\section{CARBONATE-FREE HCl-SOLUBLE DATA}

To assess the relative nondetrital and carbonate-free inputs of elements to sediments at each of the backarc sites, the $\mathrm{HCl}$-soluble concentrations of each element were carbonate corrected using the method of Dymond et al. (1976). Such a procedure allows the removal of the varying dilutive effect of biogenic carbonate for an individual sample and has been widely used in assessing variations in the hydrothermal component of sediments, both in the Lau Basin (Hodkinson and Cronan, 1991; Walter et al., 1990) and in other areas (e.g., North Fiji Basin; McMurtry et al., in press).

These data are summarized for each site in Table 3. The highest mean concentrations of $\mathrm{Mn}, \mathrm{Fe}, \mathrm{Co}, \mathrm{Ni}, \mathrm{Cu}, \mathrm{Zn}, \mathrm{Pb}, \mathrm{P}$, and $\mathrm{V}$ occur at Sites 834 and 835 with lower values at Sites 836 to 839 . Mean Mn values, for example, in Sites 834 and 835 are around twice those found at Sites 836 to 839 . A similar trend is seen in the maximum values of these elements at each site, with Sites 834 and 835 showing higher maximum values for $\mathrm{Mn}, \mathrm{Fe}, \mathrm{Ni}, \mathrm{Cu}, \mathrm{Zn}$, and $\mathrm{P}$ than Sites 836 to 839 . High maximum values of $\mathrm{Co}$ and $\mathrm{Pb}$ also occur at Sites 834 and 835 , but with additional high maximum concentrations at Site 837 , in the case of $\mathrm{Co}$, and at Site 838 , in the case of $\mathrm{Pb}$. 
Table 2. Summary of mean, minimum, and maximum weight percent soluble and percentage of each element soluble in hot, $50 \% \mathrm{HCl}$ at Sites 834 through 839.

\begin{tabular}{|c|c|c|c|c|c|c|}
\hline Element & $\begin{array}{c}\text { Site } 834 \\
(N=219)\end{array}$ & $\begin{array}{l}\text { Site } 835 \\
(N=248)\end{array}$ & $\begin{array}{l}\text { Site } 836 \\
(N=41)\end{array}$ & $\begin{array}{l}\text { Site } 837 \\
(N=91)\end{array}$ & $\begin{array}{l}\text { Site } 838 \\
(N=136)\end{array}$ & $\begin{array}{l}\text { Site } 839 \\
(N=137)\end{array}$ \\
\hline \multicolumn{7}{|l|}{ Wt\% sol. $(\%)$ : } \\
\hline Mean & 72 & 79 & 56 & 45 & 51 & 50 \\
\hline Minimum & 10 & 12 & 26 & 16 & 5 & 6 \\
\hline Maximum & 98 & 91 & 78 & 93 & 86 & 83 \\
\hline \multicolumn{7}{|l|}{$\mathrm{Li}(\mathrm{ppm}):$} \\
\hline Mean & 68 & 69 & 54 & 57 & 65 & 58 \\
\hline Minimum & 14 & 20 & 20 & 13 & 17 & 13 \\
\hline Maximum & 100 & 100 & 100 & 100 & 100 & 100 \\
\hline \multicolumn{7}{|l|}{$\mathrm{K}(\%):$} \\
\hline Mean & 72 & 80 & 56 & 54 & 56 & 52 \\
\hline Minimum & 14 & 8 & 36 & 7 & 5 & 6 \\
\hline Maximum & 100 & 100 & 77 & 100 & 94 & 91 \\
\hline \multicolumn{7}{|l|}{$\mathrm{Be}(\mathrm{ppm})$ : } \\
\hline Mean & 79 & 87 & 74 & 72 & 70 & 68 \\
\hline Minimum & 15 & 10 & 43 & 26 & 13 & 15 \\
\hline Maximum & 100 & 100 & 100 & 100 & 100 & 100 \\
\hline \multicolumn{7}{|l|}{$\operatorname{Mg}(\%):$} \\
\hline Mean & 80 & 83 & 53 & 69 & 62 & 63 \\
\hline Minimum & 34 & 45 & 29 & 24 & 11 & 25 \\
\hline Maximum & 100 & 100 & 76 & 95 & 97 & 93 \\
\hline \multicolumn{7}{|l|}{$\mathrm{Ca}(\%):$} \\
\hline Mean & 93 & 96 & 91 & 86 & 76 & 84 \\
\hline Minimum & 37 & 49 & 63 & 35 & 10 & 26 \\
\hline Maximum & 100 & 100 & 100 & 100 & 100 & 100 \\
\hline \multicolumn{7}{|l|}{$\mathrm{Al}(\%):$} \\
\hline Mean & 64 & 70 & 46 & 48 & 48 & 47 \\
\hline Minimum & 9 & 20 & 26 & 8 & 2 & 5 \\
\hline Maximum & 90 & 100 & 69 & 84 & 87 & 79 \\
\hline \multicolumn{7}{|l|}{ Ti (ppm): } \\
\hline Mean & 67 & 69 & 41 & 46 & 48 & 43 \\
\hline Minimum & 10 & 21 & 18 & 6 & 3 & 6 \\
\hline Maximum & 93 & 91 & 66 & 76 & 94 & 79 \\
\hline \multicolumn{7}{|l|}{$V(p p m):$} \\
\hline Mean & 91 & 94 & 66 & 76 & 72 & 73 \\
\hline Minimum & 38 & 56 & 34 & 33 & 9 & 29 \\
\hline Maximum & 100 & 100 & 95 & 100 & 100 & 100 \\
\hline \multicolumn{7}{|l|}{$\operatorname{Mn}(\%):$} \\
\hline Mean & 96 & 99 & 97 & 90 & 86 & 86 \\
\hline Minimum & 35 & 63 & 85 & 34 & 8 & 18 \\
\hline Maximum & 100 & 100 & 100 & 100 & 100 & 100 \\
\hline \multicolumn{7}{|l|}{$\mathrm{Fe}(\%)$} \\
\hline Mean & 88 & 92 & 66 & 70 & 71 & 68 \\
\hline Minimum & 22 & 30 & 38 & 14 & 5 & 10 \\
\hline Maximum & 100 & 100 & 91 & 100 & 100 & 100 \\
\hline Co (ppm): & & & & & & \\
\hline Mean & 92 & 95 & 74 & 83 & 81 & 79 \\
\hline Minimum & 30 & 42 & 41 & 33 & 18 & 29 \\
\hline Maximum & 100 & 100 & 100 & 100 & 100 & 100 \\
\hline $\mathrm{Ni}(\mathrm{ppm})$ : & & & & & & \\
\hline Mean & 97 & 99 & 96 & 95 & 96 & 96 \\
\hline Minimum & 63 & 83 & 83 & 50 & 50 & 44 \\
\hline Maximum & 100 & 100 & 100 & 100 & 100 & 100 \\
\hline $\mathrm{Cu}$ (ppm): & & & & & & \\
\hline Mean & 94 & 96 & 83 & 88 & 85 & 85 \\
\hline Minimum & 52 & 69 & 56 & 33 & 22 & 28 \\
\hline Maximum & 100 & 100 & 100 & 100 & 100 & 100 \\
\hline $\mathrm{Zn}(\mathrm{ppm}):$ & & & & & & \\
\hline Mean & 94 & 97 & 81 & 78 & 79 & 77 \\
\hline Minimum & 21 & 52 & 54 & 13 & 6 & 13 \\
\hline Maximum & 100 & 100 & 100 & 100 & 100 & 100 \\
\hline $\mathrm{Pb}$ (ppm): & & & & & & \\
\hline Mean & 95 & 95 & 98 & 92 & 95 & 92 \\
\hline Minimum & 35 & 45 & 77 & 43 & 50 & 24 \\
\hline Maximum & 100 & 100 & 100 & 100 & 100 & 100 \\
\hline $\mathrm{P}(\mathrm{ppm}):$ & & & & & & \\
\hline Mean & 94 & 97 & 87 & 82 & 81 & 81 \\
\hline Minimum & 23 & 34 & 65 & 27 & 7 & 10 \\
\hline Maximum & 100 & 100 & 100 & 100 & 100 & 100 \\
\hline
\end{tabular}

Table 3. Summary of mean, minimum, and maximum HCl-soluble and carbonate-corrected element concentrations at Sites 834 through 839.

\begin{tabular}{|c|c|c|c|c|c|c|}
\hline Element & $\begin{array}{l}\text { Site } 834 \\
(N=219)\end{array}$ & $\begin{array}{l}\text { Site } 835 \\
(N=248)\end{array}$ & $\begin{array}{l}\text { Site 836 } \\
(N=41)\end{array}$ & $\begin{array}{l}\text { Site } 837 \\
(N=91)\end{array}$ & $\begin{array}{l}\text { Site } 838 \\
(N=136)\end{array}$ & $\begin{array}{l}\text { Site } 839 \\
(N=137)\end{array}$ \\
\hline \multicolumn{7}{|l|}{$\mathrm{Li}(\mathrm{ppm}):$} \\
\hline Mean & 9 & 12 & 7 & 11 & 9 & 8 \\
\hline Minimum & 1. & 2 & 1 & 1 & 1 & 1 \\
\hline Maximum & 36 & 81 & 61 & 27 & 22 & 23 \\
\hline \multicolumn{7}{|l|}{ K (\%): } \\
\hline Mean & 0.91 & 0.83 & 0.39 & 0.51 & 0.46 & 0.45 \\
\hline Minimum & 0.04 & 0.23 & 0.20 & 0.06 & 0.05 & 0.05 \\
\hline Maximum & 3.24 & 1.93 & 0.70 & 1.31 & 1.63 & 1.28 \\
\hline \multicolumn{7}{|l|}{$\mathrm{Be}(\mathrm{ppm})$} \\
\hline Mean & 0.82 & 0.81 & 0.49 & 0.55 & 0.48 & 0.45 \\
\hline Minimum & 0.12 & 0.16 & 0.14 & 0.11 & 0.10 & 0.11 \\
\hline Maximum & 3.10 & 1.83 & 1.22 & 1.40 & 1.21 & 1.25 \\
\hline \multicolumn{7}{|l|}{$\mathrm{Mg}(\%):$} \\
\hline Mean & 1.45 & 1.46 & 1.02 & 1.19 & 1.08 & 1.14 \\
\hline Minimum & 0.28 & 0.56 & 0.51 & 0.24 & 0.13 & 0.19 \\
\hline Maximum & 9.40 & 2.57 & 1.61 & 2.17 & 2.08 & 3.83 \\
\hline \multicolumn{6}{|l|}{$\mathrm{CaCO}_{3}(\%) ;$} & 334 \\
\hline Minimum & 4.2 & 3.9 & 11.1 & 2.4 & 0.8 & 1.8 \\
\hline Maximum & 86.2 & 77.9 & 58.3 & 66.6 & 66.5 & 62.1 \\
\hline \multicolumn{7}{|l|}{$\mathrm{Al}(\%):$} \\
\hline Mean & 3.26 & 3.49 & 2.79 & 2.81 & 2.86 & 2.91 \\
\hline Minimum & 0.53 & 1.22 & 1.29 & 0.44 & 0.15 & 0.27 \\
\hline Maximum & 7.07 & 6.12 & 4.58 & 5.19 & 6.29 & 6.68 \\
\hline \multicolumn{7}{|l|}{$\mathrm{Ti}(\mathrm{ppm}):$} \\
\hline Mean & 2043 & 2106 & 1467 & 1573 & 1726 & 1531 \\
\hline Minimum & 376 & 430 & 627 & 143 & 169 & 111 \\
\hline Maximum & 6222 & 3993 & 3246 & 3522 & 5470 & 3074 \\
\hline \multicolumn{7}{|l|}{ V (ppm): } \\
\hline Mean & 344 & 346 & 210 & 166 & 174 & 183 \\
\hline Minimum & 22 & 37 & 109 & 15 & 7 & 8 \\
\hline Maximum & 1918 & 991 & 371 & 534 & 412 & 460 \\
\hline \multicolumn{7}{|l|}{ Mn $(\%):$} \\
\hline Mean & 4.15 & 4.86 & 2.32 & 1.67 & 2.15 & 1.60 \\
\hline Minimum & 0.04 & 0.13 & 0.47 & 0.04 & 0.01 & 0.01 \\
\hline Maximum & 14.50 & 13.85 & 6.24 & 6.25 & 5.95 & 5.15 \\
\hline \multicolumn{7}{|l|}{$\mathrm{Fe}(\%):$} \\
\hline Mean & 7.92 & 8.31 & 5.59 & 5.17 & 5.10 & 5.17 \\
\hline Minimum & 0.53 & 1.34 & 2.90 & 0.31 & 0.22 & 0.22 \\
\hline Maximum & 18.63 & 13.65 & 8.84 & 12.58 & 9.51 & 12.05 \\
\hline \multicolumn{7}{|l|}{ Co (ppm): } \\
\hline Mean & 45 & 50 & 30 & 37 & 33 & 29 \\
\hline Minimum & 3 & 5 & 14 & 3 & 2 & 2 \\
\hline Maximum & 212 & 92 & 51 & 151 & 89 & 83 \\
\hline \multicolumn{7}{|l|}{$\mathrm{Ni}(\mathrm{ppm})$ : } \\
\hline $\begin{array}{l}\text { Mean } \\
\text { Minimum }\end{array}$ & $\begin{array}{r}163 \\
10\end{array}$ & $\begin{array}{r}215 \\
29\end{array}$ & $\begin{array}{r}114 \\
29\end{array}$ & $\begin{array}{r}91 \\
3\end{array}$ & $\begin{array}{r}105 \\
2\end{array}$ & $\begin{array}{r}90 \\
3\end{array}$ \\
\hline Maximum & 418 & 577 & 232 & 248 & 334 & 306 \\
\hline \multicolumn{7}{|l|}{$\mathrm{Cu}(\mathrm{ppm}):$} \\
\hline Mean & 362 & 403 & 251 & 208 & 209 & 202 \\
\hline Minimum & 20 & 66 & 90 & 13 & 7 & 12 \\
\hline Maximum & 1256 & 785 & 472 & 580 & 540 & 555 \\
\hline \multirow{2}{*}{\multicolumn{7}{|c|}{$\begin{array}{c}\mathrm{Zn}(\mathrm{ppm}) \text { : } \\
\text { Mean }\end{array}$}} \\
\hline & 202 & 227 & 128 & 113 & 121 & 113 \\
\hline Minimum & 19 & 39 & 59 & 7 & 6 & 7 \\
\hline Maximum & 602 & 885 & 321 & 368 & 251 & 590 \\
\hline $\mathrm{Pb}(\mathrm{ppm})$ : & & & & & & \\
\hline Mean & 77 & 72 & 40 & 47 & 54 & 45 \\
\hline Minimum & 10 & 11 & 11 & 10 & 11 & 12 \\
\hline Maximum & 212 & 318 & 78 & 100 & 242 & 109 \\
\hline P (ppm): & & & & & & \\
\hline Mean & 3036 & 3187 & 1857 & 1635 & 1539 & 1652 \\
\hline Minimum & 146 & 226 & 445 & 103 & 62 & 90 \\
\hline Maximum & 7617 & 9173 & 4042 & 3598 & 4049 & 4433 \\
\hline
\end{tabular}


From this data it is clear that, for all the backarc sites, the maximum nondetrital, carbonate-free concentrations of elements with a known hydrothermal association occur at Sites 834 and 835, with significantly lower levels at Sites 836 to 839.

\section{MULTIVARIATE STATISTICS}

To assess interelement associations in the nondetrital and carbonate-free fraction of the sediments, and to see which samples are most strongly influenced by particular sedimentary components, factor analysis was performed on the $\mathrm{HCl}$-soluble, carbonate-free data. The factor analysis technique enables a larger number of variables (in this case, chemical elements) to be grouped into a lesser number of factors, each of which is a linear function (transformation) of the element concentrations and is based on the element associations inherent in a suitably conditioned correlation matrix (Howarth, 1983). The relative influence of each factor on individual samples is then determined by means of factor scores.

By applying this technique to $\mathrm{HCl}$-leached and carbonate corrected data, the effects of two major sources of variance in the bulk uncorrected data-biogenic carbonate and volcaniclastic detritushave been removed. The effect of these two dominant and antipathetically varying sediment components is to mask variations in the hydrothermal component of the sediments, and thus their removal by selective leach and statistical methods allows a closer assessment of the variability in the hydrothermal sediment phase to be made (Hodkinson and Cronan, 1991).

Using this technique for both the total data set and data from each of the six backarc sites taken separately, factor analysis has resolved two similar factors in all cases, accounting for between $75.9 \%$ and $94.7 \%$ of the data variance. The factor loadings for the total data set are given in Table 4, and loadings for each individual site are given in Table 5.

\section{Factor 1}

Factor 1 shows high loadings of $\mathrm{Mn}, \mathrm{Fe}, \mathrm{Co}, \mathrm{Ni}, \mathrm{Cu}, \mathrm{Zn}, \mathrm{Pb}, \mathrm{V}$, and $\mathrm{P}$ and accounts for $55.5 \%$ of the data variance in the total data set and between $58.4 \%$ and $74.5 \%$ of the data variance at the individual backarc sites (Tables 4-5).

Such an association of elements is typical of a "hydrothermal oxide" sediment phase, with both $\mathrm{Mn}$ and $\mathrm{Fe}$ oxyhydroxides being widely seen in lithologic examinations of the recovered cores (Parson, Hawkins, Allan, et al., 1992). Such oxides have been shown to be widespread and principally of hydrothermal origin in previous studies of Lau Basin surface sediments (Cronan et al., 1984, 1986; Hodkinson et al., 1986; Reich et al., 1990; Hodkinson and Cronan, 1991) and to coprecipitate such elements as $\mathrm{Co}, \mathrm{Ni}, \mathrm{Cu}, \mathrm{Zn}, \mathrm{Pb}$, and V (Cronan, 1976).

The association of $\mathrm{P}$ with these elements has also been noted in hydrothermal-oxide-enriched surface sediments in the Lau Basin (Hodkinson and Cronan, 1991) and, based on studies of hydrothermal sediments at the East Pacific Rise, has been accounted for in terms of a model of adsorption of seawater $\mathrm{P}$ by poorly crystalline Fe oxide (Berner, 1973). Thus, Factor 1 can be termed a "hydrothermal oxide" factor.

\section{Factor 2}

Factor 2 shows high loadings of $\mathrm{Mg}, \mathrm{Al}$, and $\mathrm{Ti}$ and accounts for $20.4 \%$ of the data variance in the total data set and between $17.7 \%$ and $27.8 \%$ of the data variance at each site (Tables 4 and 5). In addition, in the total data set and at Sites 836 through $839, \mathrm{Fe}$ also shows a degree of loading on this factor.

As the $\mathrm{HCl}$ leach removes all but the resistant detrital material from the sediments (see previous sections), this factor is likely to represent a combination of several sedimentary components that factor analysis is unable to distinguish between as they exhibit enrich-
Table 4. Varimax rotated factor loadings for two factors obtained for the hot, $50 \%$ HCl-soluble fraction of sediments from all backarc sites.

\begin{tabular}{lcc}
\hline & \multicolumn{2}{c}{ Variable } \\
\cline { 2 - 3 } Element & Factor 1 & Factor 2 \\
\hline $\mathrm{Mg}$ & 0.15 & 0.82 \\
$\mathrm{Al}$ & 0.16 & $\mathbf{0 . 9 2}$ \\
$\mathrm{Ti}$ & 0.26 & $\mathbf{0 . 8 1}$ \\
$\mathrm{V}$ & 0.73 & -0.13 \\
$\mathrm{Mn}$ & 0.87 & -0.29 \\
$\mathrm{Fe}$ & 0.89 & 0.36 \\
$\mathrm{Co}$ & 0.62 & 0.11 \\
$\mathrm{Ni}$ & 0.85 & -0.20 \\
$\mathrm{Cu}$ & 0.91 & -0.19 \\
$\mathrm{Zn}$ & $\mathbf{0 . 9 1}$ & -0.13 \\
$\mathrm{~Pb}$ & $\mathbf{0 . 7 7}$ & -0.13 \\
$\mathrm{P}$ & 0.90 & -0.17 \\
Variance (\%) & 55.5 & 20.4 \\
Cumulative variance (\%) & 55.5 & 75.9
\end{tabular}

Note: Data have been carbonate corrected before statistical analysis $(N=872)$. Element loadings that are significant for each factor appear in bold italic type.

ment in similar elements. Such components are likely to include partially weathered volcaniclastic material, halmyrolytic products such as smectite and kaolinite (recognized in small quantities in Lau Basin surface sediments by Walter et al. [1990]) and other minor components such as aeolian dust, all of which contain elevated concentrations of $\mathrm{Mg}, \mathrm{Al}$, and $\mathrm{Ti}$. In addition, the fact that the factor matrices for the total data set and for Sites 836 through 839 show a degree of loading of $\mathrm{Fe}$ indicates that some of the leachable $\mathrm{Fe}$ is likely to be of nonhydrothermal origin, associated with the above phases. A similar pattern has been noted in Lau Basin surface sediments (Hodkinson and Cronan, 1991). The fact that this association is not seen in Sites 834 and 835 probably reflects the higher proportion of hydrothermally associated Fe oxide and the lesser amount of weathered volcaniclastic material at these sites (see previous sections).

Based on previous studies of Lau Basin surface sediment lithology and mineralogy (Hodkinson et al., 1986; Reich et al., 1990; Walter et al., 1990), it is probable that weathered volcaniclastic material is quantitatively the most important sedimentary component influencing this factor and is thus termed a "weathered volcaniclastic" factor.

In comparison with factor analysis conducted on surface sediments in the Lau Basin, the two factors resolved here define very similar nondetrital sediment components to those identified in surface sediments (Hodkinson and Cronan, 1991). In that study, a "hydrothermal oxide" factor and a "weathered detrital" factor were identified, both of which showed similar loadings of elements to those described here. In the study of surface sediments, however, a third factor was also identified that showed loadings of $\mathrm{Zn}, \mathrm{Cu}$, and $\mathrm{Fe}$. This was defined as a "sulfide/weathered sulfide products" factor and was associated with sediments from, or immediately adjacent to, the active spreading centers in the basin. In the study of sediments from the six ODP backarc sites, no such factor has been identified, indicating an important difference between the hydrothermal products seen at depth in the basin and those recorded in the surface sediments adjacent to the presently active spreading centers. The absence of evidence for such a sulfide phase would suggest that the backarc sites studied here were not immediately adjacent to a hydrothermal discharge zone, where sulfide products are likely to be found, at the time of sediment accumulation.

\section{FACTOR SCORES}

By means of factor scores for Factor 1 (the hydrothermal oxide factor), it is possible to assess the relative hydrothermal influence on individual sediment samples. By using scores from Factor 1, which has a loading of nine elements associated with the hydrothermal oxide phase of the sediments, it is possible to obtain a more representative 
Table 5. Varimax rotated factor loadings for two factors obtained for the hot, $50 \% \mathrm{HCl}$-soluble fraction of sediments from Sites 834 through 839 .

\begin{tabular}{|c|c|c|}
\hline \multirow[b]{2}{*}{ Element } & \multicolumn{2}{|c|}{ Variable } \\
\hline & Factor 1 & Factor 2 \\
\hline \multicolumn{3}{|l|}{ Site $834(N=219)$ : } \\
\hline $\mathrm{Mg}$ & 0.02 & 0.65 \\
\hline $\mathrm{Al}$ & -0.07 & 0.90 \\
\hline $\mathrm{Ti}$ & 0.06 & 0.87 \\
\hline $\mathrm{V}$ & 0.68 & 0.07 \\
\hline Mn & 0.92 & -0.02 \\
\hline $\mathrm{Fe}$ & 0.80 & 0.12 \\
\hline Co & 0.69 & 0.01 \\
\hline $\mathrm{Ni}$ & 0.85 & -0.09 \\
\hline $\mathrm{Cu}$ & 0.89 & -0.05 \\
\hline $\mathrm{Zn}$ & 0.86 & 0.08 \\
\hline $\mathrm{Pb}$ & 0.76 & 0.05 \\
\hline $\mathrm{P}$ & 0.88 & -0.02 \\
\hline Variance $(\%)$ & 58.4 & 21.6 \\
\hline Cumulative variance $(\%)$ & 58.4 & 80.0 \\
\hline \multicolumn{3}{|l|}{ Site $835(N=248)$ : } \\
\hline $\mathrm{Mg}$ & 0.05 & -0.79 \\
\hline $\mathrm{Al}$ & -0.06 & -0.86 \\
\hline $\mathrm{Ti}$ & 0.08 & -0.75 \\
\hline V & 0.87 & 0.24 \\
\hline Mn & 0.83 & 0.19 \\
\hline $\mathrm{Fe}$ & 0.94 & -0.08 \\
\hline Co & 0.80 & -0.13 \\
\hline $\mathrm{Ni}$ & 0.78 & 0.19 \\
\hline $\mathrm{Cu}$ & 0.91 & 0.19 \\
\hline $\mathrm{Zn}$ & 0.91 & 0.19 \\
\hline $\mathrm{Pb}$ & 0.88 & 0.16 \\
\hline $\mathrm{P}$ & 0.84 & -0.25 \\
\hline Variance $(\%)$ & 66.8 & 23.0 \\
\hline Cumulative variance (\%) & 66.8 & 89.8 \\
\hline \multicolumn{3}{|l|}{ Site $836(N=41)$ : } \\
\hline $\mathrm{Mg}$ & 0.27 & 0.90 \\
\hline $\mathrm{Al}$ & 0.11 & 0.91 \\
\hline $\mathrm{Ti}$ & 0.06 & 0.94 \\
\hline $\mathrm{V}$ & 0.89 & 0.39 \\
\hline $\mathrm{Mn}$ & 0.99 & -0.04 \\
\hline $\mathrm{Fe}$ & 0.92 & 0.54 \\
\hline Co & 0.84 & 0.34 \\
\hline $\mathrm{Ni}$ & 0.98 & 0.05 \\
\hline $\mathrm{Cu}$ & 0.96 & 0.21 \\
\hline $\mathrm{Zn}$ & 0.93 & 0.19 \\
\hline $\mathrm{Pb}$ & 0.88 & 0.29 \\
\hline P & 0.87 & 0.21 \\
\hline Variance $(\%)$ & 74.5 & 20.2 \\
\hline Cumulative variance $(\%)$ & 74.5 & 94.7 \\
\hline
\end{tabular}

\begin{tabular}{|c|c|c|}
\hline \multirow{2}{*}{ Element } & \multicolumn{2}{|c|}{ Variable } \\
\hline & Factor 1 & Factor 2 \\
\hline \multicolumn{3}{|l|}{ Site $837(N=91)$ : } \\
\hline $\mathrm{Mg}$ & 0.27 & 0.91 \\
\hline $\mathrm{Al}$ & 0.21 & 0.93 \\
\hline $\mathrm{Ti}$ & 0.28 & 0.89 \\
\hline V & 0.81 & 0.52 \\
\hline Mn & 0.85 & 0.19 \\
\hline $\mathrm{Fe}$ & 0.81 & 0.54 \\
\hline Co & 0.86 & 0.25 \\
\hline $\mathrm{Ni}$ & 0.87 & 0.27 \\
\hline $\mathrm{Cu}$ & 0.90 & 0.24 \\
\hline $\mathrm{Zn}$ & 0.55 & 0.33 \\
\hline $\mathrm{Pb}$ & 0.71 & 0.09 \\
\hline $\mathrm{P}$ & 0.79 & 0.32 \\
\hline Variance $(\%)$ & 69.9 & 17.7 \\
\hline Cumulative variance $(\%)$ & 69.9 & 87.6 \\
\hline \multicolumn{3}{|l|}{ Site $838(N=136)$ : } \\
\hline $\mathrm{Mg}$ & 0.25 & 0.90 \\
\hline $\mathrm{Al}$ & -0.03 & 0.90 \\
\hline $\mathrm{Ti}$ & 0.21 & 0.71 \\
\hline V & 0.94 & -0.15 \\
\hline $\mathrm{Mn}$ & 0.82 & -0.14 \\
\hline $\mathrm{Fe}$ & 0.88 & 0.57 \\
\hline Co & 0.78 & 0.30 \\
\hline $\mathrm{Ni}$ & 0.91 & -0.27 \\
\hline $\mathrm{Cu}$ & 0.97 & -0.12 \\
\hline $\mathrm{Zn}$ & 0.95 & -0.05 \\
\hline $\mathrm{Pb}$ & 0.73 & -0.01 \\
\hline $\mathrm{P}$ & 0.90 & -0.16 \\
\hline Variance $(\%)$ & 63.8 & 26.0 \\
\hline Cumulative variance $(\%)$ & 63.8 & 89.8 \\
\hline \multicolumn{3}{|l|}{ Site $839(N=137)$ : } \\
\hline $\mathrm{Mg}$ & 0.23 & 0.86 \\
\hline $\mathrm{Al}$ & 0.28 & 0.86 \\
\hline $\mathrm{Ti}$ & 0.29 & 0.72 \\
\hline $\mathrm{V}$ & 0.72 & 0.20 \\
\hline $\mathrm{Mn}$ & 0.84 & -0.03 \\
\hline $\mathrm{Fe}$ & 0.85 & 0.48 \\
\hline Co & 0.79 & 0.04 \\
\hline $\mathrm{Ni}$ & 0.84 & -0.39 \\
\hline $\mathrm{Cu}$ & 0.84 & -0.34 \\
\hline $\mathrm{Zn}$ & 0.88 & -0.19 \\
\hline $\mathrm{Pb}$ & 0.80 & -0.25 \\
\hline $\mathrm{P}$ & 0.85 & -0.12 \\
\hline Variance $(\%)$ & 62.8 & 27.8 \\
\hline Cumulative variance (\%) & 62.8 & 90.6 \\
\hline
\end{tabular}

Note: Data have been carbonate corrected before statistical analysis. Element loadings that are significant for each factor appear in bold italic type.

assessment of the variability in hydrothermal input to the sediments than by using just single elements of known hydrothermal association.

The scores for Factor 1 have been calculated for each sample, based on the factor loading matrices given in Tables 4 and 5. Factor scores for each data set on which the factor analysis was performed have a mean value of 0 and a standard deviation of 1 . Thus, any sample with a score of +1 or greater is one of the $16 \%$ of samples in that data set with the highest scores on that factor (i.e., most hydrothermally enriched), whereas a sample with a score of +2 or greater is one of the $2.3 \%$ of samples in that data set with the highest scores.

\section{Factor Scores for All Sites}

In the case of the total data set, the factor scores enable a relative assessment to be made of which samples show the strongest hydrothermal influence irrespective of which backarc site they are from. To assess whether any of the six backarc sites shows an overall higher hydrothermal input to them compared with other sites, a one-way analysis of variance procedure (ANOVA) was carried out on the Factor 1 scores. This technique accepts or rejects a null hypotheses that two or more sample groups are derived from the same population at a pre-set confidence level (the 95\% c.l. is used here). In this case, the technique provides a statistical test to see if the means of the Factor 1 scores are significantly different at the separate backarc sites.
The results of this procedure are graphically represented in Figure 2 and clearly show that the mean hydrothermal inputs to Sites 834 and 835 are both similar and significantly higher than at the other backarc sites. For Sites 836 to 839 , mean hydrothermal inputs are similar at Sites 837,838 , and 839 whereas mean hydrothermal input at Site 836 is slightly lower.

\section{Scores for Each Site}

For the factor analysis conducted on data subsets for each site, Factor 1 scores represent a relative loading for each sample from within a single backarc site, indicating the degree of hydrothermal influence on that sample relative to other samples from the same site. By this means it is possible to assess the downhole, and hence the temporal variability, of hydrothermal inputs at each of the backarc sites separately.

\section{RECALCULATION OF SEDIMENTARY SEQUENCES}

Significant proportions of the sedimentary sections at all backarc sites sampled during Leg 135 contain both redeposited clayey nannofossil ooze intervals and/or intervals of epiclastic volcanic ash deposition (see "Core Lithologies" section, this chapter; Parson, Hawkins, Allan, et al., 1992). To assess the downhole variability in hydrother- 


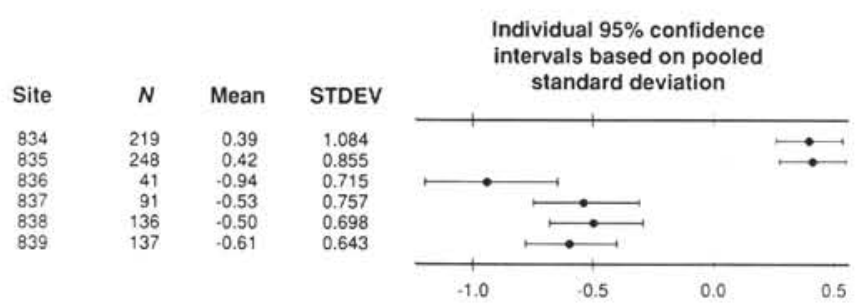

Figure 2. Summary of one-way analysis of variance (ANOVA) results on Factor 1 scores for all Lau Basin backarc sites. $N=$ number of samples, Mean $=$ mean of Factor 1 scores, and STDEV = standard deviation on mean.

mal inputs to the pelagic sediment intervals alone, and thus arrive at a more accurate assessment of the temporal variability in hydrothermal input at each site, the thickness of the sediment section at each site has been recalculated by removing these redeposited, nonpelagic intervals. At Sites 834 and 835, detailed work by Rothwell et al. (this volume) has identified the redeposited intervals. We have undertaken similar work at Sites 836 to 839 , based on shipboard sedimentological studies (Parson, Hawkins, Allan, et al., 1992). Subsequently, the thickness of only the pelagic sedimentary section at each site has been summed and the depth below seafloor of individual samples used in this work recalculated. All depths referred to in the subsequent descriptions of downhole variability are quoted as recalculated depths below seafloor (mbsf).

\section{DOWNHOLE VARIABILITY IN THE HYDROTHERMAL FACTOR SCORES FOR INDIVIDUAL BACKARC SITES}

Downhole plots of Factor 1 scores for each backarc site are shown in Figures 3 to 8.

At all sites, variability in the hydrothermal input to the sediments occurs on a small scale, as would be expected given the short-term temporal variability of hydrothermal systems. However, general downhole trends, peaks in hydrothermal input, and periods of enhanced rate of change in the hydrothermal input are clearly visible. A clear overall trend of an increase in hydrothermal input is present uphole from the base of the sediment section to a maximum, thence a decrease to the surface at all but Site 836 .

\section{Sites 834 and 835}

Downhole variations in the hydrothermal input at Sites 834 and 835 (Figs. 3-4) are similar. At each site, an overall increase in hydrothermal input from the base of the section to a maxima (at 54.7 and $43.3 \mathrm{mbsf}$, respectively) occurs before a decrease toward the top of the section. At both sites, perturbations in this general trend occur.

At Site 834 (Fig. 3), significant peaks in hydrothermal input are superimposed on the general trend and are seen at around 2.0,3.1, 9.5, 16.7-18.8, 26.7, 28.4, 32.75, 45.0, 48.3, 51.1, 54.7 (maximum for this site), 60.9, 61.75, 64.8, 69.7, and 73.3 mbsf. Variations in the rate of change in the hydrothermal input to the sediments are also seen downhole. Between 12.0 and 16.7,32.75 and 39.0,42.0 and 54.7, and $54.7 \mathrm{mbsf}$ and the base of the section, rates of change in the hydrothermal input are significantly higher than those in the other intervals.

At Site 835 (Fig. 4), significant peaks in hydrothermal inputs, although less well defined, also occur superimposed on the general downhole trend. These occur at around 4.1, 8.25, 14.5, 17.6, 21.1, $28.25,34.0,38.75,48.95-49.25$ (maximum for this site), 50.0, and 51.2 mbsf. Similarly, variations in the rate of change in the hydrothermal input to the sediments are recognized at Site 835 and, in particular, are enhanced between 10.0 and $14.5 \mathrm{mbsf}$ and between $43.3 \mathrm{mbsf}$ and the base of the section when compared with other depth intervals at this site.
Factor 1 scores

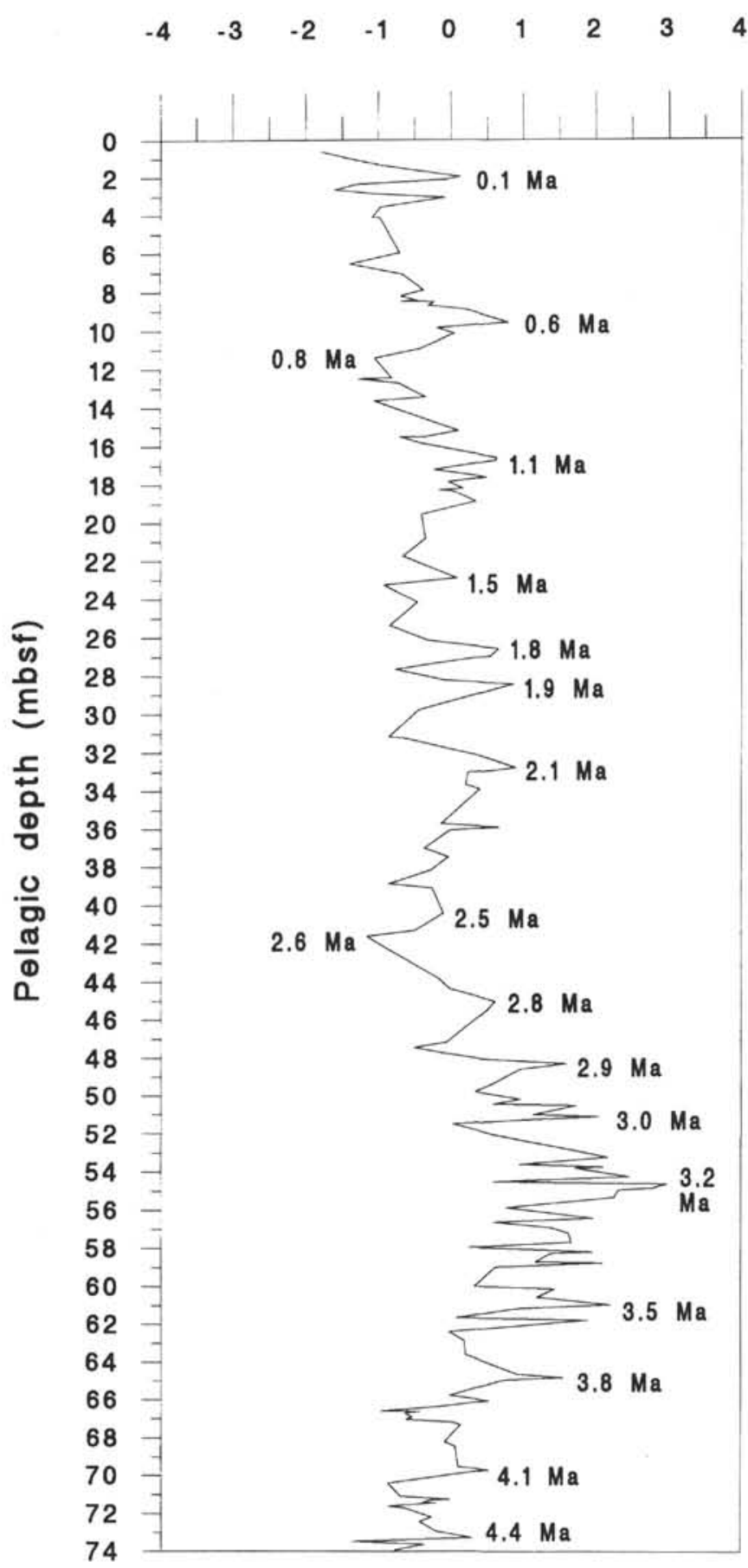

Figure 3. Downhole plot of Factor 1 scores for Site 834. Depths in mbsf are recalculated depths for pelagic sedimentary intervals only. All ages are in Ma and are rounded to the nearest $0.1 \mathrm{Ma}$

\section{Site 836}

At Site 836 (Fig. 5), maximum hydrothermal input occurs as a peak slightly above the base of the section at $14.25 \mathrm{mbsf}$.

Clear trends are difficult to establish because the sedimentary section is relatively thin; in general, however, an overall decrease in hydrothermal input uphole can be seen, with the exception of the region of low input between 14.24 and 10.9 mbsf. Above 10.9 mbsf, 


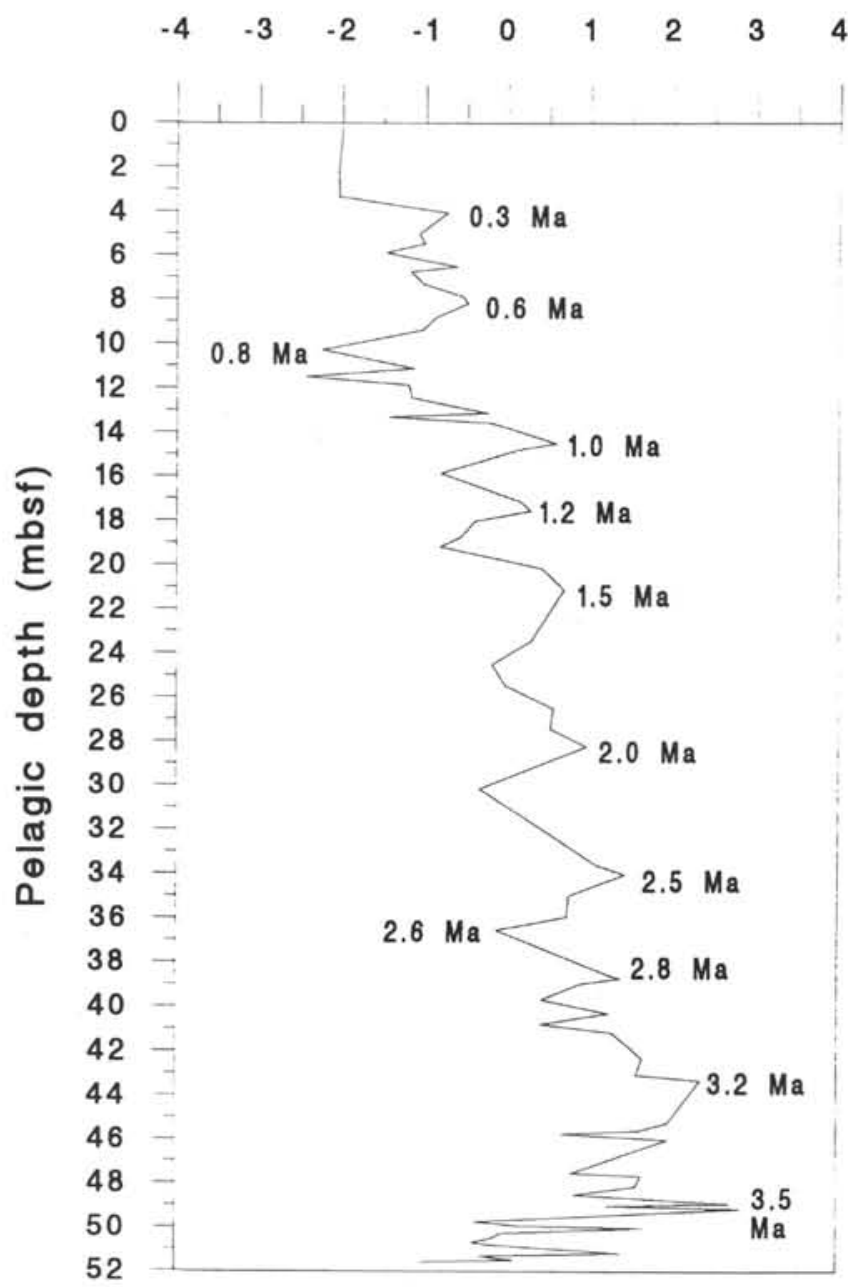

Figure 4. Downhole plot of Factor 1 scores for Site 835. Plot conventions as in Figure 3.

an overall decrease in input is more evident, although significant peaks in hydrothermal input are superimposed on the trend at 5.3 and 9.5 mbsf.

\section{Site $\mathbf{8 3 7}$}

At Site 837 (Fig. 6), although considerable downhole variability occurs, a general trend of increasing hydrothermal input can be seen between the base of the section and maximum input at $23.1 \mathrm{mbsf}$. Hydrothermal input then decreases toward the top of the section. Peaks of hydrothermal input are seen at 4.9, 10.7, 12.3, 17.6, 20.0, $24.2,27.3,28.7$, and, toward the base of the section, at $35.8 \mathrm{mbsf}$. Periods of rapid rate of change in the hydrothermal input to the sedimentary sequence are recognized above the peak at $23.1 \mathrm{mbsf}$, below the peak at $24.2 \mathrm{mbsf}$, and also between 14.5 and $17.6 \mathrm{mbsf}$.

\section{Sites 838 and 839}

Downhole trends in hydrothermal input are similar at Sites 838 and 839 (Figs. 7-8) with an overall increase from the base of the section to 9.15 and $8.5 \mathrm{mbsf}$, respectively, before decreasing toward the top of the sediment section. Prominent peaks in input occur at around 5.8, 9.15 (maximum for this site), 12.3, 16.0, 20.75, 23.25, 25.2, and 30.35 mbsf at Site 838 and at 4.75-5.4, 8.5 (maximum for

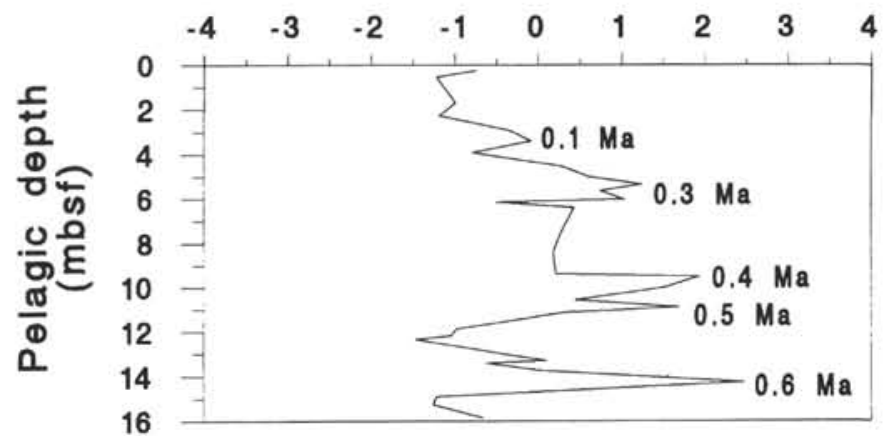

Figure 5. Downhole plot of Factor 1 scores for Site 836. Plot conventions as in Figure 3.

\section{Factor 1 scores}

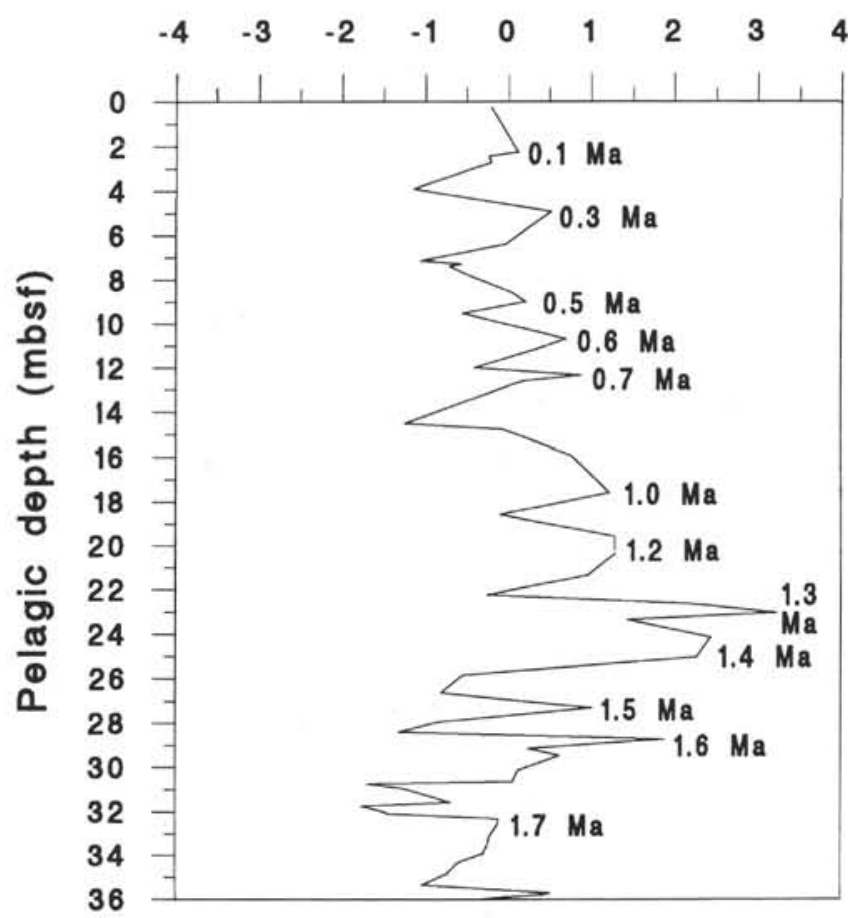

Figure 6. Downhole plot of Factor 1 scores for Site 837. Plot conventions as in Figure 3.

this site), 10.75, 12.70, 24.25, 28.75-29.5,31.2, and 33.5 mbsf at Site 839. Variations in the rate of change of hydrothermal input are again evident at both sites, with such rates being high between the surface and $5.8 \mathrm{mbsf}$ and above and below the peaks at 23.25 and $30.35 \mathrm{mbsf}$ at Site 838 , and between the surface and $8.5 \mathrm{mbsf}$ and associated with the peaks at 24.25 and $29.5 \mathrm{mbsf}$ at Site 839 .

\section{TIMING OF PERIODS OF ENHANCED HYDROTHERMAL INPUT AT EACH SITE}

To compare variations in the hydrothermal input at each site, the ages of prominent peaks in input have been determined, based on a combination of shipboard and post-cruise data. 


\section{Factor 1 scores}

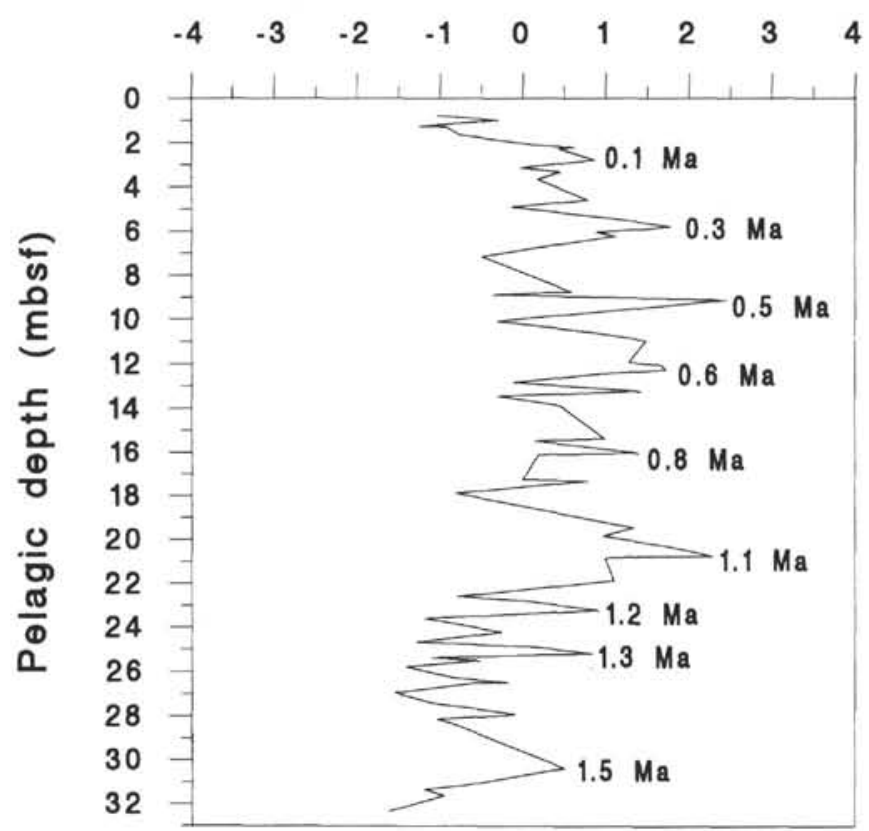

Figure 7. Downhole plot of Factor 1 scores for Site 838. Plot conventions as in Figure 3.

For Sites 834 and 835, Rothwell et al. (this volume) have defined sediment ages using shipboard paleomagnetic data and additional biostratigraphic data obtained post-cruise for the pelagic intervals in Unit I sediments (see Parson, Hawkins, Allan, et al. [1992] for lithostratigraphic descriptions). Below Unit I, sediment ages have been established from shipboard paleomagnetic data applied to the recalculated pelagic sedimentary intervals identified by Rothwell et al. (this volume). For Sites 836 to 839 , sediment ages have been determined from shipboard paleomagnetic data and the pelagic sedimentary intervals established here, based on shipboard data (see "Recalculation of Sedimentary Sequence" section, this chapter).

The high proportion of resedimented material and the occurrence of rapidly deposited volcaniclastic sediment intervals seen at all sites, when combined with uncertainties in paleomagnetic and biostratigraphic age determinations (see Parson, Hawkins, Allan, et al., 1992), may lead to some inaccuracy in the age determinations for pelagic sediment intervals. Such data do, however, provide the best estimates of sediment ages currently available and are used here.

Based on this data, the sedimentary sequences studied here record the hydrothermal activity in the basin back to $4.5 \mathrm{Ma}$ (Site 834), 3.7 Ma (Site 835), 0.7 Ma (Site 836), 1.9 Ma (Site 837), 1.8 Ma (Site 838 ), and $2.0 \mathrm{Ma}$ (Site 839 ). Ages (to the nearest $0.1 \mathrm{Ma}$ ) of significant peaks in hydrothermal input at each site are shown in Figures 3-8, and correlatable peaks and periods of enhanced rates of change in the hydrothermal input between sites are described below.

\section{Sites 834 and 835}

In terms of the general downhole trends in hydrothermal input at Sites 834 and 835 (see previous section; Figs. 3-4), the peak in the period of enhanced hydrothermal input occurs at $3.2 \mathrm{Ma}$ at both sites. Above this, a period of rapid decrease in hydrothermal input occurs over a comparable time period at both sites, extending from 3.2 to 2.6 Ma. Below 3.2 Ma a significant peak in hydrothermal input at Site 835 (maximum for that site) occurs at $3.5 \mathrm{Ma}$ whereas a peak of similar age, although not the maximum for the site, also occurs in Site
Factor 1 scores

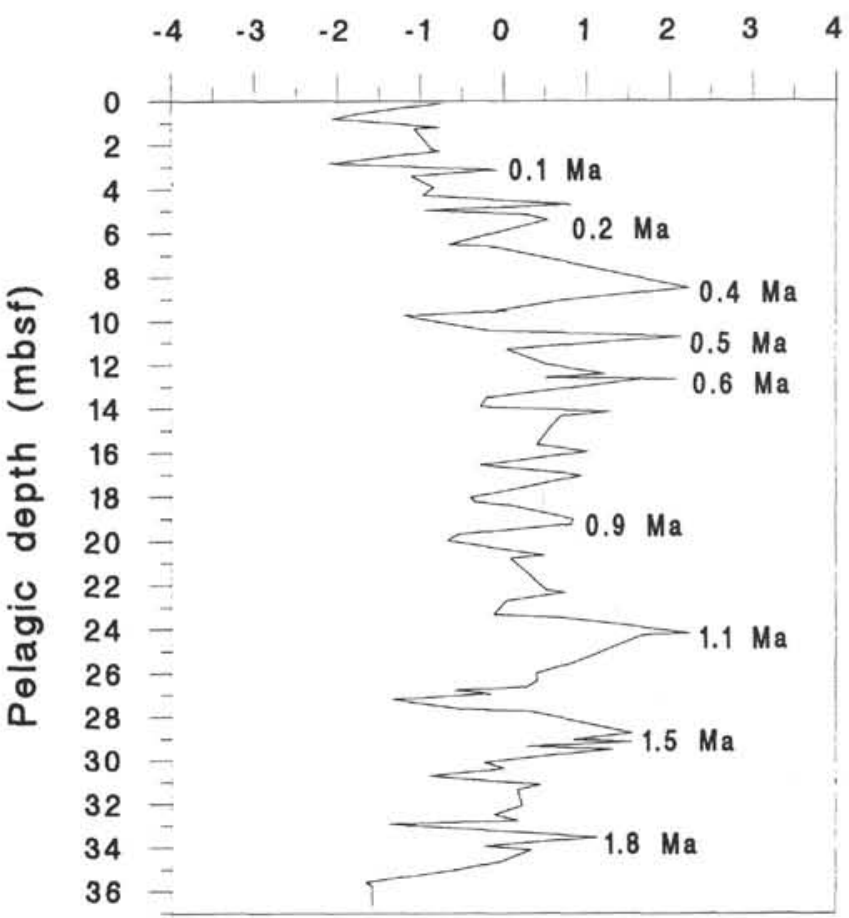

Figure 8. Downhole plot of Factor 1 scores for Site 839. Plot conventions as in Figure 3.

834. Between 1.1 and $0.8 \mathrm{Ma}$ in Site 834 and between 1.0 and $0.8 \mathrm{Ma}$ in Site 835, a period of rapid decrease in hydrothermal input is recognized followed by an increase in input to a peak at $0.6 \mathrm{Ma}$, again concomitant at both sites.

\section{Site $\mathbf{8 3 6}$}

At Site 836 (Fig. 5), prominent peaks in hydrothermal input have ages of $0.1,0.3,0.4-0.5$, and $0.6 \mathrm{Ma}$ (maximum), with a period of low input occurring between 0.5 and $0.6 \mathrm{Ma}$.

\section{Site 837}

At Site 837 (Fig. 6), the period of maximum hydrothermal input occurs at 1.3 to $1.4 \mathrm{Ma}$ with additional significant peaks occurring at $1.0,1.2,1.5$, and 1.6 Ma. Although geographically close, the correlation of peaks in hydrothermal input between Sites 836 and 837 is difficult because of the short sedimentary section recovered at Site 836 in comparison with the one recovered at Site 837. Peaks of similar age in both sites do, however, occur at $0.1,0.3,0.5$, and $0.6 \mathrm{Ma}$.

\section{Sites 838 and 839}

Although the downhole trend is not as clearly defined as at Sites 834 and 835 , the age range of the period of increased hydrothermal input at Sites 838 and 839 (Figs. 7-8) is similar at both sites, ranging between 0.3 and $0.6 \mathrm{Ma}$ at Site 838 and between 0.4 and $0.6 \mathrm{Ma}$ at Site 839 . Within this range three major peaks occur at both sites, with ages of $0.3,0.5$, and $0.6 \mathrm{Ma}$ at Site 838 and $0.4,0.5$, and $0.6 \mathrm{Ma}$ at Site 839. At greater depths prominent peaks in hydrothermal input of similar age are clearly recognized at 1.5 and, in particular, at $1.1 \mathrm{Ma}$ at both sites, with the peak at $1.1 \mathrm{Ma}$ being of similar intensity to the period of increased hydrothermal input between 0.3 and $0.6 \mathrm{Ma}$ in Site 838 and between 0.4 and $0.6 \mathrm{Ma}$ in Site 839 . 


\section{DISCUSSION}

It is important to recognize that the hydrothermal signature described here represents an integrated sedimentary record of hydrothermal oxide plume fallout. Similar studies of hydrothermal sediments at the East Pacific Rise (EPR) recovered during Deep Sea Drilling Project (DSDP) Leg 92 have shown that hydrothermal inputs from plume fallout are greatest near the basement at each site, with a general decrease toward the top of the hole (Lyle et al., 1986; Barrett et al., 1987). Rea and Leinen (1986) showed that, in general, a logarithmic decrease in the hydrothermal input to sediments occurred with the migration of the crust from the spreading axis. Perturbations in this general trend have, however, been documented, and Lyle et al. (1987) have related periods of significantly enhanced hydrothermal input to periods of major tectonic reorganization of the EPR. Such reorganizations are thought to have increased hydrothermal activity substantially by fracturing ocean crust and providing seawater access to deep-seated heat sources.

Studies of the hydrothermal sedimentary record adjacent to the EPR during DSDP Leg 92 relate to plume dispersion from a single, established ridge axis. In the case of the hydrothermal sedimentary record in the Lau Basin, however, hydrothermal plume dispersion is not simply from a single, established spreading center within the basin but instead reflects the complex tectonic evolution and changing styles of crustal accretion within the basin. Parson and Hawkins (this volume) propose a model of basin evolution in which crust in the western part of the basin, comprising a series of irregular ridges and troughs, formed as a result of extensional rifting and localized arc magmatism before the onset of "true" backarc spreading. This backarc spreading was initiated at the southeast end of what is now the Peggy Ridge and has generated the majority of crust in the eastern part of the basin by southward propagation of the ELSC, the propagating tip of which is now the southern limit of the Valu Fa Ridge. The southward propagation of the CLSC was also initiated at the Peggy Ridge, at between 1.2 and $1.5 \mathrm{Ma}$, and is currently propagating into backarc crust generated at the ELSC. The hydrothermal sedimentary record should reflect such evolution, with factors such as changes in ridge propagation and spreading rates, tectonic uplift and reorganization, the formation of new hydrothermal cells and resultant variations in their discharge intensity, and the occurrence of morphotectonic barriers to hydrothermal plume dispersal all affecting this sedimentary hydrothermal record.

In contrast to the EPR, all sites within the Lau Basin (with the exception of Site 836) show trends of increasing hydrothermal input uphole from basement to a region of maximum input before decreasing toward the top of the hole. Such a trend shows that, unlike the EPR, maximum hydrothermal input to sediments within the basin did not occur immediately after basement crust formation but rather at a later stage of basin history.

\section{Sites 834 and 835}

Sites 834 and 835 recovered the oldest sediments from the basin and, situated to the west of both the ELSC and CLSC on crust formed by extensional rifting, are best placed to record the hydrothermal history of the basin in relation to the propagation of both the ELSC and CLSC into the basin.

At both sites the trend of increasing hydrothermal input from basement to a region of enhanced input may reflect lower hydrothermal inputs associated with extensional crustal rifting during the deposition of the oldest sediments at both sites, followed by more intense hydrothermal activity associated with the increasing proximity of these sites to the southwardly propagating ELSC. Based on the model of Parson and Hawkins (this volume), the predicted age of the passage of the ELSC propagating tip past the latitude of Sites 834 and 835 is $3.6 \mathrm{Ma}$, some $0.4 \mathrm{Ma}$ before the peak in hydrothermal activity recorded at both sites. Such a time "lag" may reflect a delay between the passage of the propagator and the formation of a strongly discharging hydrothermal system associated with the newly formed spreading axis. This hypothesis is not at variance with observations on presentday hydrothermal activity associated with both the ELSC and CLSC, in which the most active hydrothermal fields discovered to date occur at some distance behind the propagating ridge tips (Hodkinson and Cronan, 1991; M. Sinha, pers. comm., 1992; A. Malahoff, pers. comm., 1992). The location of the most hydrothermally active part of the Valu Fa Ridge reported to date, for example, occurs at a distance behind the propagating tip of the ELSC equivalent to some $0.7 \mathrm{Ma}$ of southward propagation of the ELSC (M. Sinha, pers. comm., 1992) whereas, based on the model of Parson and Hawkins (this volume), the most hydrothermally active part of the CLSC (Hodkinson and Cronan, 1991) occurs at a distance behind the propagating tip equivalent to some $0.5 \mathrm{Ma}$ of propagation of the CLSC. It should be noted, however, that the location of such fields is based on studies to date that have concentrated on these regions and the existence of strongly active systems closer to the propagating tips cannot be ruled out.

Above the 3.2 Ma peak at both sites, the overall trend to the surface is one of decreasing hydrothermal input, although peaks in the hydrothermal record occur superimposed on this trend. Such a pattern of decrease is what would be expected as seafloor spreading of the crust generated by the ELSC increases the distance between both Sites 834 and 835 and the site of hydrothermal discharge at the ELSC.

In the model of basin evolution proposed by Parson and Hawkins (this volume), the southward propagation of the CLSC into crust generated by the ELSC would be expected to produce a signature of a peak in hydrothermal input followed by a subsequent decrease, similar to that related to the ELSC. The peak should, however, have a lower intensity relative to that associated with the ELSC as the distance between sites and the CLSC was greater, because of subsequent crust generation at the ELSC, than that between the sites and the ELSC at the time of hydrothermal input to the sediment record. At both sites such a peak occurs at $0.6 \mathrm{Ma}$, immediately following a period of rapid decrease in input between 1.1-1.0 and 0.8 Ma. Following the peak at $0.6 \mathrm{Ma}$, inputs at both sites again decrease, although peaks at younger ages are seen at $0.1 \mathrm{Ma}$ at Site 834 and at $0.3 \mathrm{Ma}$ at Site 835. Although such a pattern of a peak in hydrothermal input related to the southward propagation of the CLSC would be expected, the discrepancy in age between the timing of the peak $(0.6$ Ma) and the projected passage of the CLSC $(0.5 \mathrm{Ma}$, based on the model of Parson and Hawkins [this volume]) is difficult to explain. If a "lag" between the passage of the propagator and the period of most intense hydrothermal input to the sediment record occurs, comparable to the peak associated with the passage of the ELSC, the peak in input to the sediments should occur at a younger age. Although such peaks do occur, they are less well defined than the one occurring at $0.6 \mathrm{Ma}$ and are not concomitant at both sites (Figs. 3-4). Small discrepancies in the age determinations of the peaks or the timing of propagation of the CLSC may account for this, or, alternatively, the younger peaks in hydrothermal input may be related to the passage of the CLSC rather than the peaks at $0.6 \mathrm{Ma}$. If the present-day site of intense hydrothermal discharge at the CLSC is around the latitude of Sites 834 and 835 , a peak should be seen in the youngest sediments recovered at these sites. That such peaks are not prominent, although a peak at $0.1 \mathrm{Ma}$ can be seen at Site 834 and another one at $0.3 \mathrm{Ma}$ can be seen at Site 835, may be a result of present-day basin morphology, with both sites being located in a region of narrow basins and interbasin highs. Such features may act as partial barriers to hydrothermal plume dispersion and thus inhibit a strong hydrothermal input to the sedimentary record at Sites 834 and 835 .

Between 1.1-1.0 and $0.8 \mathrm{Ma}$, a rapid decrease in hydrothermal input occurs at both Sites 834 and 835 before an increase in input to the peak at $0.6 \mathrm{Ma}$. Parson and Hawkins (this volume), based on interpretations of magnetic data, have suggested that between 1.0 and $0.6 \mathrm{Ma}$ crustal spreading rates were significantly enhanced in this part of the basin, possibly related to the southward propagation of the 
CLSC into the basin (L. Parson, pers. comm., 1992). Such an increase in spreading rate would be reflected in a more rapid decrease in hydrothermal input to the sediments at Sites 834 and 835 at this time as the distance between them and the site of hydrothermal discharge is increased more rapidly because of enhanced crustal spreading rates. Thus, periods of both reduced and enhanced rates of change in hydrothermal input, such as described here between 1.1-1.0 and 0.6 $\mathrm{Ma}$ at Sites 834 and 835 , may be a reflection of variations in crustal spreading rates within the basin.

\section{Sites 836 to 839}

The location of Sites 836 to 839 to the west of the ELSC and some distance south of the CLSC makes them primarily of use in assessing the temporal variability of the hydrothermal record associated with the evolution of the ELSC alone.

Site 836 is located on crust generated at the ELSC, with an basement age of $0.7 \mathrm{Ma}$ estimated from the biostratigraphic and paleomagnetic data and an age of $>0.9 \mathrm{Ma}$ based on the model of Parson and Hawkins (this volume). The sedimentary record at this site, therefore, records the hydrothermal history in this part of the basin post-ELSC propagation. We expect that this record would be more analogous to that of the EPR, showing a decrease in hydrothermal input uphole from basement, as the hydrothermal system associated with the adjacent spreading ridge (the ELSC) would be established before sediment accumulation at Site 836. With the exception of a period of particularly low input between 0.5 and $0.6 \mathrm{Ma}$, such a trend is seen. If this region of low hydrothermal input is anomalous in an overall decreasing-uphole trend from $0.6 \mathrm{Ma}$ or if the peak at $0.6 \mathrm{Ma}$ is anomalous in a region of overall low input below $0.5 \mathrm{Ma}$ is difficult to establish, given the short sediment section and sampling resolution available here.

Site 837 is postulated by Parson and Hawkins (this volume) to be located on crust characteristic of propagator tip basement and thus formed at the propagating tip of the ELSC, at a predicted age of 2.0 Ma. Based on this model, if a "lag" between propagator passage and the generation of maximum hydrothermal input at the site does occur, the peak in hydrothermal input recorded at Site 837 should be located above the base of the sedimentary section as at Sites 834 and 835 . Such a pattern in hydrothermal input can be seen, with an overall increase in input from the base of the section to a peak at $1.3-1.4 \mathrm{Ma}$ before a general decrease to surface, as the relative distance between the site and the ridge axis increases because of crust generation at the ELSC. Data for this site suggests a $0.6-0.7 \mathrm{Ma}$ "lag" between ridge propagation and maximum hydrothermal input, significantly longer than that seen at Sites 834 and 835 .

Sites 838 and 839 are both postulated by Parson and Hawkins (this volume) to lie on crust formed by extensional rifting, with an estimated age of $1.7 \mathrm{Ma}$ for the closest passage of the southwardly propagating ELSC past this latitude. Being located close to each other in the same sub-basin, a similar record of hydrothermal input would be expected at both sites. Overall, both sites show a very similar downhole trend, increasing from the base of the hole to a broad region of maximum input between 0.3 and $0.6 \mathrm{Ma}$ at Site 838 and between 0.4 and $0.6 \mathrm{Ma}$ at Site 839 before decreasing toward the surface. Such a trend is again what would be expected given that the period of maximum hydrothermal input may occur sometime after the passage of the propagator. Estimates of timing of the propagator passage and the age of these peaks in hydrothermal input yield considerable "lags", ranging from 1.1 to 1.4 Ma between the two events. In addition to this period of generally high input, however, a significant peak in input also occurs at $1.1 \mathrm{Ma}$ at both sites. This peak is of comparable intensity to the region of high input at a younger age in both sites, and it is possible that it may more accurately reflect a period of high hydrothermal input at the sites associated with the formation of a strongly discharging hydrothermal system at the ELSC, resulting in a "lag" of some 0.6 Ma. Such a figure would be more comparable with that seen at Site 837 .

Superimposed on the general trends at all sites, significant peaks in hydrothermal input have been recognized. Such peaks in input may be a result of variations in the discharge characteristics of the hydrothermal systems related to periods of tectonism within the basin, as described at the EPR by Lyle et al. (1987). In addition, peaks in hydrothermal input may reflect the style of ridge propagation in the basin, with intermittent or stepwise propagation of the spreading ridges (as postulated by Parson and Hawkins, this volume) also producing peaks in the hydrothermal record. Our current understanding of basin tectonics, however, does not enable specific tectonic events to be correlated with these perturbations in the hydrothermal record. Further work to refine such correlations is needed. In addition, factors such as basin morphology, particularly in the region of Sites 834 and 835 where narrow basins occur separated by interbasin highs, are likely to affect hydrothermal plume dispersion and the consequent sedimentary hydrothermal record.

\section{SUMMARY AND CONCLUSIONS}

Multivariate statistics demonstrate that the hydrothermal phase of the sediments at all Leg 135 sites comprises Fe and Mn oxides with associated coprecipitated elements. No evidence of hydrothermal sulfides or their weathered products was seen, suggesting that the sites were not immediately adjacent to a zone of hydrothermal discharge, where such phases are likely to occur, at the time of sediment accumulation.

Sites 834 and 835 have significantly higher mean and maximum hydrothermal inputs than the other backarc sites. The period of most intense hydrothermal input in this part of the basin occurred at 3.2 Ma.

Clear downhole trends in the hydrothermal input to the sedimentary sequence were recognized at Sites 834 and 835 , with a period of increased hydrothermal input occurring at depth at both sites. Above and below this, a general trend of decreasing hydrothermal input was seen. The timing of this peak at $3.2 \mathrm{Ma}$ in both sites, when compared with the proposed model of basin evolution, suggests that a delay or "lag" of some $0.4 \mathrm{Ma}$ occurred between the closest passage of the southwardly propagating ELSC and the period of most intense hydrothermal input recorded in the sediment section at both sites. Subsequent to this peak, an expected decrease in the hydrothermal input to the sediments was seen as the relative distance between the sites and the ELSC increased because of crustal spreading.

Propagation of the CLSC into the basin may also be reflected by a peak in hydrothermal input in the sedimentary record at both sites, although a discrepancy exists between the timing of such a peak and the proposed age of propagation of the CLSC past this latitude, which is still unresolved.

At the remaining backarc sites, although general trends are less distinct, similar increases to those seen at Sites 834 and 835 from the base of the section to a peak before a decline toward surface are seen at all but Site 836 . Such a pattern again fits the model in which a "lag" occurs between propagator passage and the full development of a hydrothermal system at the spreading ridge. The age of the period of "lag" does, however, appear to vary among the sites, ranging from 0.6 to $0.7 \mathrm{Ma}$ at Site 837 and from 1.1 to $1.4 \mathrm{Ma}$ at Sites 838 and 839 , although a peak at $1.1 \mathrm{Ma}$ (resulting in a "lag" of $0.6 \mathrm{Ma}$ ) at Sites 838 and 839 may more accurately reflect the period of intense input subsequent to ELSC propagation.

Variations in the period of "lag" seen at the backarc sites may be real or may be caused by problems in identifying which peaks are associated with the ridge propagation (e.g., Sites 838 and 839 ) or by inaccuracies in timing of tectonic and hydrothermal events. The data would suggest, however, that a period of time elapsed between the formation of a spreading ridge by rift propagation and the hydrothermal system associated with it becoming fully established and producing the period of maximum hydrothermal input seen in the sediment record. 
In contrast to the other backarc sites, Site 836 is located on crust generated at the ELSC post-ridge propagation and would be expected to show a hydrothermal record more analogous to that of the EPR. Although not definitive, the hydrothermal record seen may support this.

Superimposed on the overall downhole trend at all sites, peaks in hydrothermal input were recognized. Such peaks may be related to periods of tectonic reorganization of the spreading complexes, which may cause enhanced hydrothermal activity, as has been proposed by Lyle et al. (1987) for the EPR, and/or an intermittent, stepwise style of ridge propagation. Further study and refining of hydrothermal peak and tectonic event timing is required to relate such peaks to tectonic events associated with the spreading complexes. Morphotectonic features within the basin may also affect the hydrothermal record seen, with narrow basins and interbasin highs affecting hydrothermal plume dispersion.

Variations in crustal spreading rates may be reflected in the hydrothermal sedimentary record in the form of periods of enhanced and reduced rates of change in hydrothermal input.

\section{ACKNOWLEDGMENTS}

R.A.H. was funded by the NERC, U.K., under ODP Special Topic Research Grant GST/02/442. Funds were also provided for Mrs. K. St. Clair-Gribble, whose help with chemical analyses for the project is gratefully acknowledged. In addition, NERC provided funds for R.A.H. to participate on Leg 135 and at the subsequent post-cruise meeting. Thanks are owed to the master, crew, and technical staff of the JOIDES Resolution for their efforts during Leg 135 and to the Leg 135 Scientific Party. L.M. Parson and R.G. Rothwell of IOSDL are acknowledged for their many helpful discussions on basin tectonics and sedimentation patterns, respectively.

\section{REFERENCES $*$}

Barrett, T.J., Taylor, P.N., and Lugowski, J., 1987. Metalliferous sediments from DSDP Leg 92: the East Pacific Rise transect. Geochim. Cosmochim. Acta, 51:2241-2253.

Berner, R.A., 1973. Phosphate removal from seawater by adsorption on volcanogenic ferric oxides. Earth Planet. Sci. Lett., 18:77-86.

Bertine, K.K., 1974. Origin of Lau Basin Rise sediment. Geochim. Cosmochim. Acta, 38:629-640.

Bertine, K.K., and Keene, J.B., 1975. Submarine barite-opal rocks of hydrothermal origin. Science, 188:150-152.

Cronan, D.S., 1976. Basal metalliferous sediments from the eastern Pacific. Geol. Soc. Am. Bull., 87:928-934.

, 1983. Metalliferous sediments in the CCOP/SOPAC region of the Southwest Pacific, with particular reference to geochemical exploration for the deposits. CCOP/SOPAC Tech. Bull., 4.

Cronan, D.S., Hodkinson, R.A., Harkness, D.D., Moorby, S.A., and Glasby, G.P., 1986. Accumulation rates of hydrothermal metalliferous sediments in the Lau Basin, S.W. Pacific. Geo.-Mar. Lett., 6:51-56.

Cronan, D.S., Moorby, S.A., Glasby, G.P., Knedler, K., Thomson, J., and Hodkinson, R.A., 1984. Hydrothermal and volcaniclastic sedimentation on the Tonga-Kermadec Ridge and its adjacent marginal basins. Geol. Soc. Spec. Publ. London, 16:137-149.

Dymond, J., Corliss, J.B., and Stillinger, R., 1976. Chemical composition and metal accumulation rates of metalliferous sediments from Sites 319, 320, and 321. In Yeats, R.S., Hart, S.R., et al., Init. Repts. DSDP, 34: Washington (U.S. Govt. Printing Office), 575-588.

Fouquet, Y., von Stackelberg, U., Charlou, J.L., Donval, J.P., Erzinger, J., Foucher, J.P., Herzig, P., Muhe, R., Soakai, S., Wiedicke, M., and White- church, H., 1990. Hydrothermal activity and metallogenesis in the Lau back-arc Basin. Nature, 349:778-781.

Hawkins, J.W., and Helu, S., 1986. Polymetallic sulphide deposit from "blacksmoker" chimney: Lau Basin. Eos, 67:378.

Hodkinson, R.A., and Cronan, D.S., 1991. Geochemistry of recent hydrothermal sediments in relation to tectonic environment in the Lau Basin, southwest Pacific. Mar. Geol., 98:353-366.

Hodkinson, R.A., Cronan, D.S., Glasby, G.P., and Moorby, S.A., 1986. Geochemistry of marine sediments from the Lau Basin, Havre Trough and Tonga-Kermadec Ridge. N.Z. J. Geol. Geophys., 29:335-344.

Howarth, R.J., 1983. Handbook of Exploration Geochemistry (Vol. 2): Statistics and Data Analysis in Geochemical Prospecting: New York (Elsevier).

Lyle, M., Leinen, M., Owen, R.M., and Rea, D.K., 1987. Late Tertiary history of hydrothermal deposition at the East Pacific Rise, $19^{\circ} \mathrm{S}$ : correlation to volcano-tectonic events. Geophys. Res. Lett., 14:595-598.

Lyle, M., Owen, R., and Leinen, M., 1986. History of hydrothermal sedimentation at the east Pacific Rise, $19^{\circ} \mathrm{S}$. In Leinen, M., Rea, D.K., et al., Init. Repts. DSDP, 92: Washington (U.S. Govt. Printing Office), 585-596.

McMurtry, G.M., De Carlo, E.H., and Kim, K.H., in press. Geochemistry of north-central North Fiji Basin sediments. In Kroenke, L.W., and Price, R.C. (Eds.), Geology and Offshore Resources of Pacific Island Arcs-Fiji Region. Circum-Pac. Counc. Energy Miner. Resour., Earth Sci. Ser., 9.

Moorby, S.A., Knedler, K.E., Glasby, G.P., Hodkinson, R.A., and Cronan, D.S., 1986. Lithology, colour, mineralogy and geochemistry of marine sediments of the Lau Basin, Havre Trough, and Tonga-Kermadec Ridge. N.Z. Oceanogr. Inst., Oceanogr. Field Rep., 27.

Parson, L., Hawkins, J., Allan, J., et al., 1992. Proc. ODP, Init. Repts., 135: College Station, TX (Ocean Drilling Program).

Parson, L.M., Pearce, J.A., Murton, B.J., Hodkinson, R.A., Bloomer, S., Ernewein, M., Huggett, Q.J., Miller, S., Johnson, L., Rodda, P., and Helu, S., 1990. Role of ridge jumps and ridge propagation in the tectonic evolution of the Lau back-arc basin, southwest Pacific. Geology, 18:470-473.

Rea, D.K., and Leinen, M., 1986. Neogene controls on hydrothermal activity and paleoceanography of the southeast Pacific. In Leinen, M., Rea, D.K., et al., Init. Repts. DSDP, 92: Washington (U.S. Govt. Printing Office), 597-617.

Reich, V., 1990. Calcareous ooze, volcanic ash, and metalliferous sediments in the Quaternary of the Lau and North Fiji Basins. Geol. Jahrb., Reihe D, 92:109-162.

Reich, V., Marchig, V., Sunkel, G., and Weiss, W., 1990. Hydrothermal and volcanic input in sediments of the Lau Back-arc Basin, S.W. Pacific. Mar. Min., 9:183-203.

Thompson, M., and Walsh, J.N., 1989. The Handbook of Inductively Coupled Plasma Spectrometry (2nd ed.): London (Blackie)

von Stackelberg, U., and Shipboard Scientific Party, 1985. Hydrothermal sulphide deposits in back-arc spreading centres in the southwest Pacific. BGR Circ., 2:3-14.

1988. Active hydrothermalism in the Lau back-arc basin (SW Pacific): first results from the Sonne 48 cruise (1987). Mar. Min., 7:431442.

Walter, P., Stoffers, P., Glasby, G.P., and Marchig, V., 1990. Major and trace element geochemistry of Lau Basin sediments. Geol. Jahrb., Reihe D, 92:163-188.

\footnotetext{
- Abbreviations for names of organizations and publication titles in ODP reference lists follow the style given in Chemical Abstracts Service Source Index (published by American Chemical Society).
}

Date of initial receipt: 22 June 1992

Date of acceptance: 1 March 1993

Ms 135SR-104 